\title{
An Eleven-Year Survey on Field Disease Susceptibility of Citrus Accessions to Colletotrichum and Alternaria Species
}

\author{
Alessandro Vitale ${ }^{1, *,+}\left(\mathbb{D}\right.$, Dalia Aiello ${ }^{1,+}+\mathbb{D}$, Antonino Azzaro ${ }^{1}$, Vladimiro Guarnaccia ${ }^{2,3}(\mathbb{D}$ \\ and Giancarlo Polizzi ${ }^{1}$ (D) \\ 1 Department of Agriculture, Food and Environment, University of Catania, Via Santa Sofia 100, \\ 95123 Catania, Italy; dalia.aiello@unict.it (D.A.); aazzaro@studioazzaro.eu (A.A.); gpolizzi@unict.it (G.P.) \\ 2 Department of Agricultural, Forest and Food Sciences (DISAFA), University of Torino, Largo Braccini 2, \\ 10095 Grugliasco, TO, Italy; vladimiro.guarnaccia@unito.it \\ 3 Centre for Innovation in the Agro-Environmental Sector, AGROINNOVA, University of Torino, \\ Largo Braccini 2, 10095 Grugliasco, TO, Italy \\ * Correspondence: alevital@unict.it \\ + A.V. and D.A. contributed equally to this work.
}

check for updates

Citation: Vitale, A.; Aiello, D.; Azzaro, A.; Guarnaccia, V.; Polizzi, G. An Eleven-Year Survey on Field Disease Susceptibility of Citrus Accessions to Colletotrichum and Alternaria Species. Agriculture 2021, 11, 536. https://doi.org/10.3390/ agriculture11060536

Academic Editors: Michelle Wirthensohn and Rodomiro Ortiz

Received: 23 April 2021

Accepted: 8 June 2021

Published: 10 June 2021

Publisher's Note: MDPI stays neutral with regard to jurisdictional claims in published maps and institutional affiliations.

Copyright: (c) 2021 by the authors. Licensee MDPI, Basel, Switzerland. This article is an open access article distributed under the terms and conditions of the Creative Commons Attribution (CC BY) license (https:// creativecommons.org/licenses/by/ $4.0 /)$.

\begin{abstract}
In the past decade Colletotrichum gloeosporioides, C. karstii, and Alternaria alternata represent emerging fungal pathogens on citrus in the Mediterranean basin. Selection of tolerant Citrus germplasm offers evaluable long-term solution and should be considered as promising alternative to limit synthetic fungicide application to manage Alternaria and Colletotrichum infections in Citrus groves. In this study, the high variability of pre-harvest disease symptoms among 37 Citrus accessions was investigated in Italy in the most representative Sicilian production districts covering 1500 ha and including 20 homogeneous areas over an eleven-year survey period (2010-2020). Early fruit drop, brown spot, and anthracnose on fruit and leaves, pre-harvest fruit drop, and twig blight and defoliation associated to Alternaria and Colletotrichum spp. were identified on oranges, mandarins, and lemons. Comprehensively, first extensive data obtained herein on field susceptibility within "Tarocco" blood orange group to above disease symptoms clearly indicate as "Tarocco Nucellare 57-1E-1," “Tarocco Tapi," “Tarocco Sant'Alfio," and "Tarocco Catania" accessions should be preferred to remaining Tarocco ones. A broad degree of tolerance or susceptibility was also observed within other Citrus group as it happens for tolerant lemon "Femminello Zagara Bianca," thus demonstrating a putative resource for further studies to employ in a breeding program for genetic improvement of Citrus.
\end{abstract}

Keywords: citrus germplasm; disease symptoms; fungal diseases; genetic improvement; blood oranges

\section{Introduction}

The cultivation of Citrus spp. represents one of the most important fruit industries worldwide. Several countries of the Mediterranean basin such as Greece, Italy, Spain, Tunisia, and Turkey are important producers of citrus fruit, as well as additional regions with Mediterranean climate such as Australia, California, Florida, and South Africa [1].

A broad range of fungal species cause diseases affecting roots, foliage, fruit, and wood where Citrus spp. are cultivated [2-8]. Interesting case studies demonstrate the ability of pathogens of citrus, as well as of additional host species, to be in continuous evolution due to climatic change, genetic diversity, and global movements of plants and materials [9-13].

Colletotrichum spp. have been treated for decades as post-harvest pathogens, though they have been recently reported as major field pathogens in Europe, California, and North Africa [5,14,15]. The adoption of the use of multi-gene phylogenetic analysis and the polyphasic protocols for studying the genus Colletotrichum recently changed the characterization and pathogen species concepts of Colletotrichum related to different fruit 
crops [9,16-18]. Thus, a broad number of species of Colletotrichum was reported in association with Citrus spp. over the world [19-24]. Colletotrichum gloeosporioides and C. abscissum (previously reported as C. acutatum) are the causal agents of petal necrosis, abscission of young fruit, and the formation of persistent calyces of various Citrus species as a disease complex known as postbloom fruit drop in Brazil [3,25] and Bermuda [26]. Key lime anthracnose is a disease complex relating to leaves, flowers, and fruits of Key lime caused by C. limetticola [27]. In Italy, Tunisia, and Turkey, heavy pre-harvest anthracnose symptoms on orange fruit and on leaves of mandarins were caused by species of Colletotrichum with the main role played by C. gloeosporioides and C. karstii [5,28-30], severe anthracnose symptoms on unripe and ripe lemon fruit were recorded in Portugal [31], mixed infections were caused by C. gloeosporioides on orange fruit in Mexico, Morocco [32,33] and on grapefruit in Mexico [34]. Moreover, twig wither-tip and dieback symptoms were observed on orange orchards in Tunisia [14], on different Citrus spp. in Pakistan [35], on sweet orange and lemon trees in Algeria, [36], and on clementine and oranges in California where symptoms included leaf chlorosis, twig and shoot dieback, crown thinning, wood cankers in branches, and death of young plants [15]. Thus, all the global reports show a new scenario of emerging Colletotrichum diseases of citrus plants involving a broad variety of symptoms including fruit and leaf spot, twig blight and defoliation, early and pre-harvest fruit drop, mostly caused by C. gloeosporioides and C. karstii, with consequent losses of marketable fruit.

In addition, Alternaria alternata (tangerine pathotype) has been considered a key pathogen mainly for the mandarin group and related hybrids [37,38]. However, this species was described in 2020 as responsible for brown spot on fruit and leaves of several sweet orange and lemon accessions cultivated in Italy [6]. The study demonstrated also the occasional association of $A$. arborescens with brown spot on Citrus sinensis. Therefore, Alternaria brown spot on fruit and leaf of several Citrus species and accessions is an additional disease complex to consider to the above mentioned Colletotrichum diseases.

Chemical management of Alternaria and Colletotrichum diseases is the main strategy to control these fungal diseases on citrus worldwide [39-41]. Critical factors are the number and timing of fungicide applications, the spray interval and the size of treated area, and the efficacy of the molecule. The high number of treatments which must be used to protect susceptible accessions could pose serious risks of environmental impact and fungicide resistance [40,42]. For these reasons, the genetic resistance remains the best long-term solution.

Very few data concern the degree of field susceptibility to Colletotrichum and Alternaria diseases of the Citrus accessions cultivated in Sicily. In a previous paper, the accession "Tarocco Scirè" was significantly more susceptible to natural infections of $C$. gloeosporioides than "Tarocco Nucellare" [5].

Therefore, the main objectives of the current study are: (i) To ascertain the symptoms in the orchards resulting in a reduction of fruit production; (ii) to identify the main fungal species responsible or associated with the symptoms observed in the field; (iii) to determine the susceptibility or tolerance of several cultivated accessions of oranges, mandarins, and lemons for agricultural purposes and for the genetic improvement of the Citrus accessions.

\section{Materials and Methods}

\subsection{Germplasm, Timing, and Location of Phytopatological Survey}

A wide disease survey was performed from 2010 to 2020 in one of the most representative Italian Citrus production districts in the eastern Sicily falling into Syracuse, Catania, and Enna provinces (Sicily-Italy). In total, 20 homogeneous production areas (each formed by 1-to-27 farms) were surveyed for each year and single data for area were grouped into three periods i.e., from 2010 to 2013 (four years), from 2014 to 2017 (four years), and from 2018 to 2020 (three years). Comprehensively, 24 orange accessions, 10 mandarin accessions, 1 Satsuma, and 2 lemon accessions were surveyed over an eleven-year period throughout the different areas. To make easier comparisons, these accessions were further grouped in 
(i) "Tarocco" blood oranges, (ii) other Blood oranges, "Valencia" orange and Navel oranges,

(iii) Mandarin, Satsuma and Easy peel group, and (iv) Lemon group.

Particular attention has been given to typical "Tarocco" blood orange production because it represents the most important Citrus group for the Italian citriculture and the most spread Citrus crop in Sicily. To this regard, 15 "Tarocco" accessions have been inspected in this study.

\subsection{Description of Disease Symptoms}

All symptoms referable to biotic factors were considered during the entire field survey whereas climatic, edaphic, and physiological disorders were from time to time discriminated. Moreover, only symptom and sign complexes representing a heavy threat for citrus production in young and mature Citrus orchards were considered and monitored over time.

\subsection{Isolation and Fungal Identification}

To ascertain the etiology of infections in the field or the associated fungi to the symptom-complexes, affected leaves, twigs, and fruit were collected from different Citrus accessions grown in the fields. Small sections of symptomatic tissue were disinfested with $1 \% \mathrm{NaOCl}$ for $1 \mathrm{~min}$, rinsed in sterile distilled water (SDW), then placed on potato dextrose agar (PDA, Oxoid, Basingstoke, UK) amended with streptomycin sulphate (Sigma-Aldrich, Saint Louis, MO, USA) at $100 \mathrm{mg} / \mathrm{L}$, and then incubated at $25 \pm 1{ }^{\circ} \mathrm{C}$ in the dark. After $7 \mathrm{~d}$, single conidia were recovered from each fungal colony following streaking a $10 \mu \mathrm{L}$ of conidial suspension on agar plate and after 12-16 h of incubation were selected and transferred into PDA Petri dishes. All isolates obtained were preliminarily identified by morphological analysis (conidia and colony morphology). Moreover, molecular analysis was used to confirm the identification at species level. Representative fungal isolates recovered from each symptom were grown on malt extract agar (MEA) for $7 \mathrm{~d}$ at room temperature $\left(20^{\circ} \mathrm{C}\right)$. Resulting mycelium of each isolate was harvested with a sterile scalpel, and the genomic DNA was extracted using the Wizard ${ }^{\circledR}$ Genomic DNA Purification Kit (Promega Corporation, Madison, WI, USA), according to the manufacturer's protocol. The internal transcribed spacer of ribosomal DNA (ITS) region was targeted for PCR amplification and sequencing of all isolates using ITS5 and ITS4 primers [43].

In addition, glyceraldehyde-3-phosphate dehydrogenase (GAPDH) and translation elongation factor 1- $\alpha(E F-1 \alpha)$ genes were selected due to their highly informative combined to distinguish A. alternata from all the other Alternaria species of the section Alternaria [6,44]. The primers used for these regions were: EF1-728F and EF1-986R for EF-1 $\alpha$ [45] and GPD1 and GPD2 for GAPDH. The PCR mixtures for ITS, GAPDH, and EF-1 $\alpha$ contained $1 \mu \mathrm{L}$ of genomic DNA, $2 \mu \mathrm{M} \mathrm{MgCl} 2,40 \mu \mathrm{M}$ of each dNTP, $0.2 \mu \mathrm{M}$ of each primer, and 0.5 Unit GoTaq ${ }^{\circledR}$ Flexi DNA polymerase (Promega, Madison, WI, USA), in a total volume of $12.5 \mu \mathrm{L}$. The PCR conditions were: initial denaturation at $94{ }^{\circ} \mathrm{C}$ for $5 \mathrm{~min} ; 35$ cycles amplification at $94{ }^{\circ} \mathrm{C}$ for $30 \mathrm{~s}$; annealing at $48^{\circ} \mathrm{C}$ (ITS) or $52^{\circ} \mathrm{C}(E F-1 \alpha)$ for $50 \mathrm{~s}$, and extension at $72{ }^{\circ} \mathrm{C}$ for $2 \mathrm{~min}$; and a final extension at $72{ }^{\circ} \mathrm{C}$ for $7 \mathrm{~min}$. The PCR products were sequenced in both directions by Macrogen Inc. (Seoul, Korea).

For species of Colletotrichum, PCR was performed with primers TubGF1 and TubGR [46], specific for partial $\beta$-tubulin ( $t u b 2)$ gene, and with primers GDF and GDR, specific for glyceraldehyde-3-phosphate dehydrogenase (GAPDH) gene. These two genes were used to distinguish fungi belonging to Colletotrichum genus [47]. Incubation mixtures for PCR contained genomic DNA, 19 reaction buffer, $2.0 \mathrm{mM} \mathrm{MgCl}$, $2001 \mathrm{M}$ each dNTP, $400 \mathrm{nM}$ of primers, and 2.5 U of Taq DNA polymerase (Sigma-Aldrich, Saint Louis, MO, USA). All reagents were mixed and maintained at $95^{\circ} \mathrm{C}$ for $3 \mathrm{~min}$. The PCR conditions were: initial denaturation at $94{ }^{\circ} \mathrm{C}$ for $1 \mathrm{~min} ; 38$ cycles of amplification at $94{ }^{\circ} \mathrm{C}$ for $30 \mathrm{~s}$; annealing at $55{ }^{\circ} \mathrm{C}$ (with primers ITS1-ITS4) or $54{ }^{\circ} \mathrm{C}$ (with primers TubGF1-TubGR and GDF-GDR) for $1 \mathrm{~min}$; extension at $72{ }^{\circ} \mathrm{C}$ for $1 \mathrm{~min}$, followed by a final extension period at $72{ }^{\circ} \mathrm{C}$ for $10 \mathrm{~min}$. PCR products were purified using Nucleospin Extract Kit (Macherey-Nagel, 
Düren, Germany) and sequenced in both directions (Stazione Zoologica "Anton Dohrn," Naples, Italy).

BLASTn searches on GenBank were performed using GAPDH and EF-1 $\alpha$ sequences for Alternaria species and tub2 and GAPDH for Colletotrichum species.

\subsection{Susceptibility Evaluation and Risk of Disease Outbreaks}

For germplasms herein tested, the disease susceptibility levels (from tolerant to extremely sensitive) versus all symptoms were referred to an empirical 0-to- 5 disease incidence scale taking into account the percentage of affected citrus organs (fruit, leaves, twigs) in the citrus canopy where $0=$ healthy canopy; $1=$ from 1 to $5 \%$ of infected fruit/leaves/twigs in the canopy; 2 = from 6 to $15 \%$ of infected fruit/leaves/twigs in the canopy; $3=$ from 16 to $30 \%$ of infected fruit/leaves/twigs in the canopy; $4=$ from 31 to $60 \%$ of infected fruit/leaves/twigs in the canopy, $5=$ from 61 up to $100 \%$ of infected fruit/leaves/twigs in the canopy.

\section{Results and Discussion}

\subsection{Disease Symptoms}

During the disease survey, several symptom-complexes were observed at different times on all Citrus accessions grown in the fields. They included early fruit drop, Alternaria brown spot on fruit and on leaf, anthracnose on leaf and fruit, pre-harvest fruit drop, twig dieback and defoliation. Symptoms of early fruit drop consisted in necrosis of citrus inflorescence (receptacle, calyx, sepals, ovary, style, and stigma) (Figure 1a-d), and subsequent fruitlets drop as a consequence of the suberization of the calix tissue (Figure 1e). Widespread blight of persistent calyx was observed (Figure 1f). Alternatively, necrotic fruitlet did not fall and remained attached to the twig (Figure 1h). Occasionally an abnormal fruit drop was detected (Figure 1g). Altogether, this symptom-complex determined heavy production losses when flowering coincides with the rainy season. The persistence of the calix observed in some cases allowed to differentiate biotic early fruit drop symptoms from the physiological early drop of Citrus fruit. During the survey orange brown lesions on petals and/or black acervuli of species of Colletotrichum, typical of post-bloom fruit drop disease (PFD), were not observed.
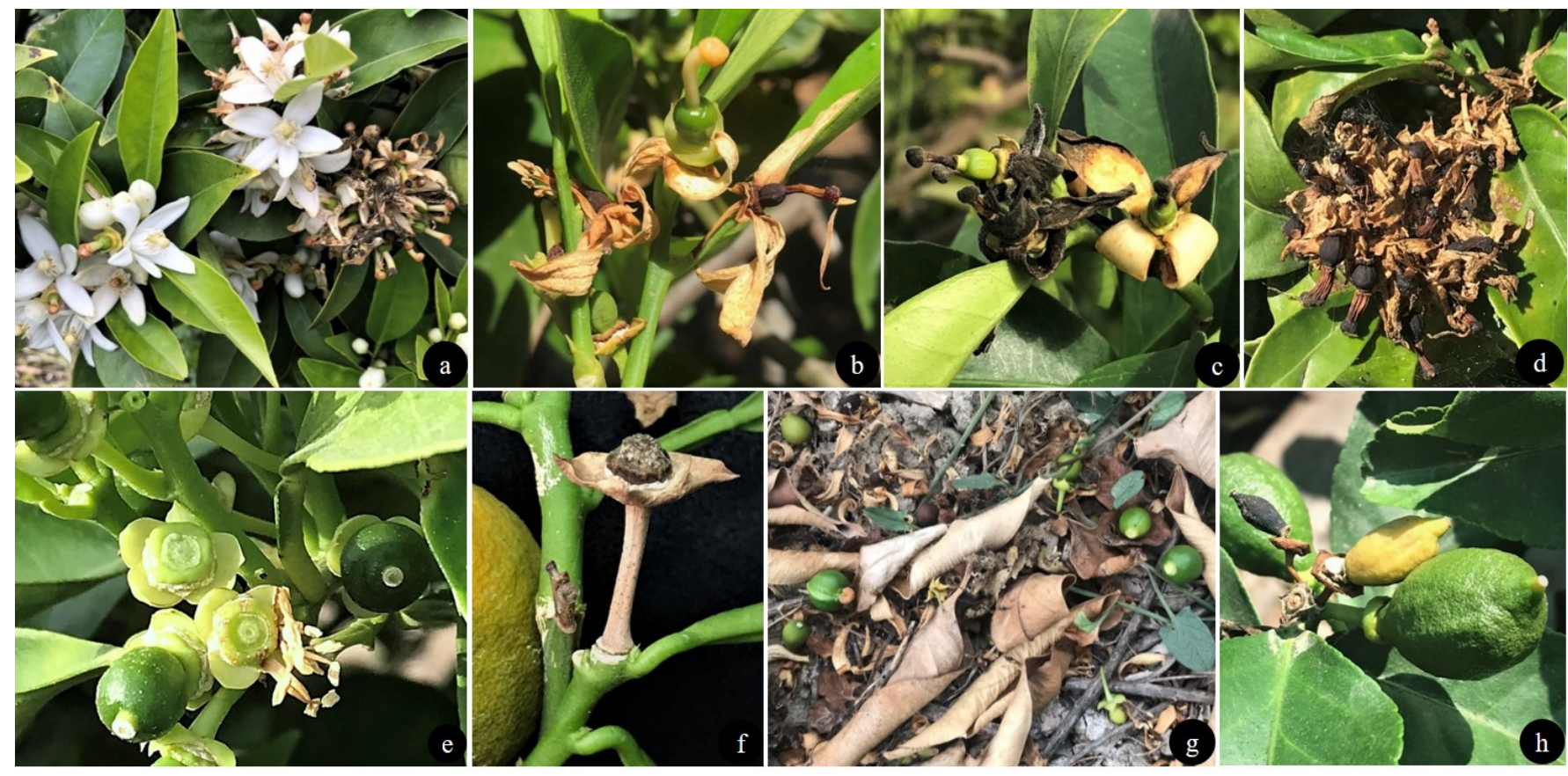

Figure 1. Early fruit drop: (a-d) blight and necrosis of citrus inflorescence; (e) fruitlets drop as a consequence of suberization of calyx tissue; (f) blight of persistent calyx; (g) abnormal early fruit drop; (h) early fruit drop. 
Symptoms referable to Alternaria brown spot was observed in fields on leaves and fruit. Severe infections on mature fruit included lesions that varied from small specks to large pockmarks on the fruit surface (Figure 2a,b). Sometimes, fruit formed a barrier of corky tissue erupting from the surface that in the later stage of the infection, can fall out forming craters (Figure 2e). On immature fruit, the symptoms included slightly depressed brown to black lesions surrounded by yellow halo areas (Figure 2c,d). In addition, gummosis on "Femminello Siracusano 2KR" lemon fruit was observed (Figure 2c). Alternaria brown spot on leaves included small, chlorotic spots on young leaves without a yellow halo (Figure 2f) that with age turned to brown or dark brown, became necrotic, enlarged, and developed yellow halos (Figure $2 \mathrm{~g}, \mathrm{~h}$ ). Alternaria brown spot on fruit determined heavy production losses with optimal environmental conditions (extended periods of leaf wetness and temperatures of less than $17^{\circ} \mathrm{C}$ ).

Severe symptoms of anthracnose were observed in fields on leaves and fruit (Figure 3a). Leaf spot appeared as irregular areas with mesophyll collapse (Figure 3b) or blighted areas grey or light brown with a prominent purple margin and the presence of black acervuli of fungus (Figure 3c). Sometimes, extension of necrosis into the leaf veins was observed determining leaf yellowing and tip wilting (Figure 3d,e). In the later phases of infection, lesions enlarged determined leaf blight (Figure $3 \mathrm{f}$ ) and showed signs of the fungus consisting of black acervuli on dead tissue. Moreover, severe infections could occur after hail damage and under high humid condition (Figure 3g).

During the survey, pre-harvest anthracnose symptoms on fruit appeared as small, light, irregular, and sunken lesions that could turn black, increase in size, with the production of acervuli on the infected tissue (Figure $4 \mathrm{a}-\mathrm{e}$ ). In some cases, the lesions regarded the stem-end of fruit causing pre-harvest fruit drop (Figure $4 \mathrm{f}$ ) or covered over the $50 \%$ of the surface of the fruit (Figure $4 \mathrm{~g}$ ). Occasionally, tear stain on fruit was observed. This symptom appeared as superficial, light brown streaks or bands along the fruit that in some cases covered a high percentage of the fruit surface (Figure $4 \mathrm{~h}$ ). In many accessions severe infections on the fruit caused heavy production losses.

During the survey we have evaluated the symptoms in all damaged areas. Pre-harvest fruit drop was observed in field during the survey (Figure 5a). In detail, symptoms consisted of calix blight and the development of light brown to blackish discoloration on the rind at or near the stem-end of the fruit (Figure 5b). Premature coloration of immature fruit (Figure $5 \mathrm{c}, \mathrm{d}$ ) and stem-end rot in longitudinal section of fruit were also observed (Figure 5e). Under conducive environmental conditions, these symptoms caused heavy fruit drop. In other cases, as the disease progressed, an extensive rot extended from peduncle to stem-end of fruit and covered a high percentage of the fruit surface (Figure $5 \mathrm{f}$ ). Moreover, when the infected fruit was cut in half, it showed black rot symptom on central column caused by the invasion and colonization of fungus (Figure 5g). Severe infections occurred with cool, moist winters, and hot and dry summers.

Severe twig dieback and defoliation symptoms were observed in the field survey (Figure 6a,b). Symptoms-complex observed included blight of twigs that appeared dry, minute brown-to-black, slightly raised or dieback of the entire branches (Figure 6c). Frequently, black acervuli of fungus appeared on dead bark and twigs. Moreover, blight of calyces and receptacles (Figure 6d) and fruitlets (Figure 6e) attached to the stem were observed. When twigs dieback progressed as a consequence the leaves wilted, turned yellow, and dropped off (Figure 6b). Mummified fruit with grey aerial hyphae (Figure 6f) and gum exudation on infected twig were also detected (Figure 6g). 

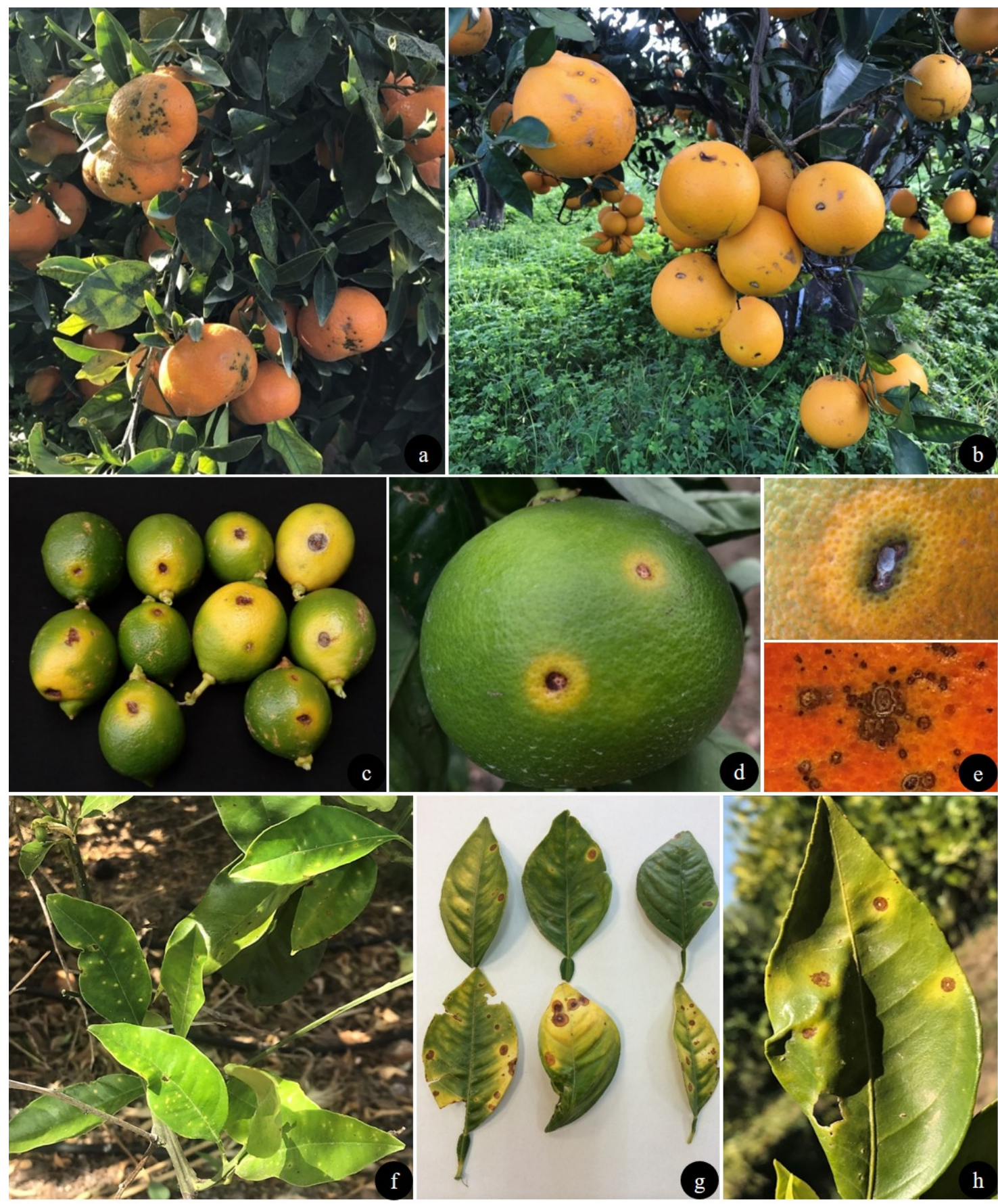

Figure 2. Alternaria brown spot: (a) brown spot on "Mandalate" mandarin; (b) brown spot on "Tarocco Scirè VCR"; (c) depressed brown to black lesions surrounded by yellow halo areas and gummosis on immature "Femminello Siracusano 2KR" lemon fruit; (d) brown spot lesions with yellow halo areas on "Tarocco Gallo VCR" immature fruit; (e) detail of fruit spots (specks to craters symptoms) on "Tarocco Sciara" (up) and "Nova" mandarin (down); (f) chlorotic leaf spots on young leaf of "Tarocco Emanuele"; $(\mathbf{g}, \mathbf{h})$ necrotic spots with yellow halo of expanded leaves of Tarocco blood oranges. 


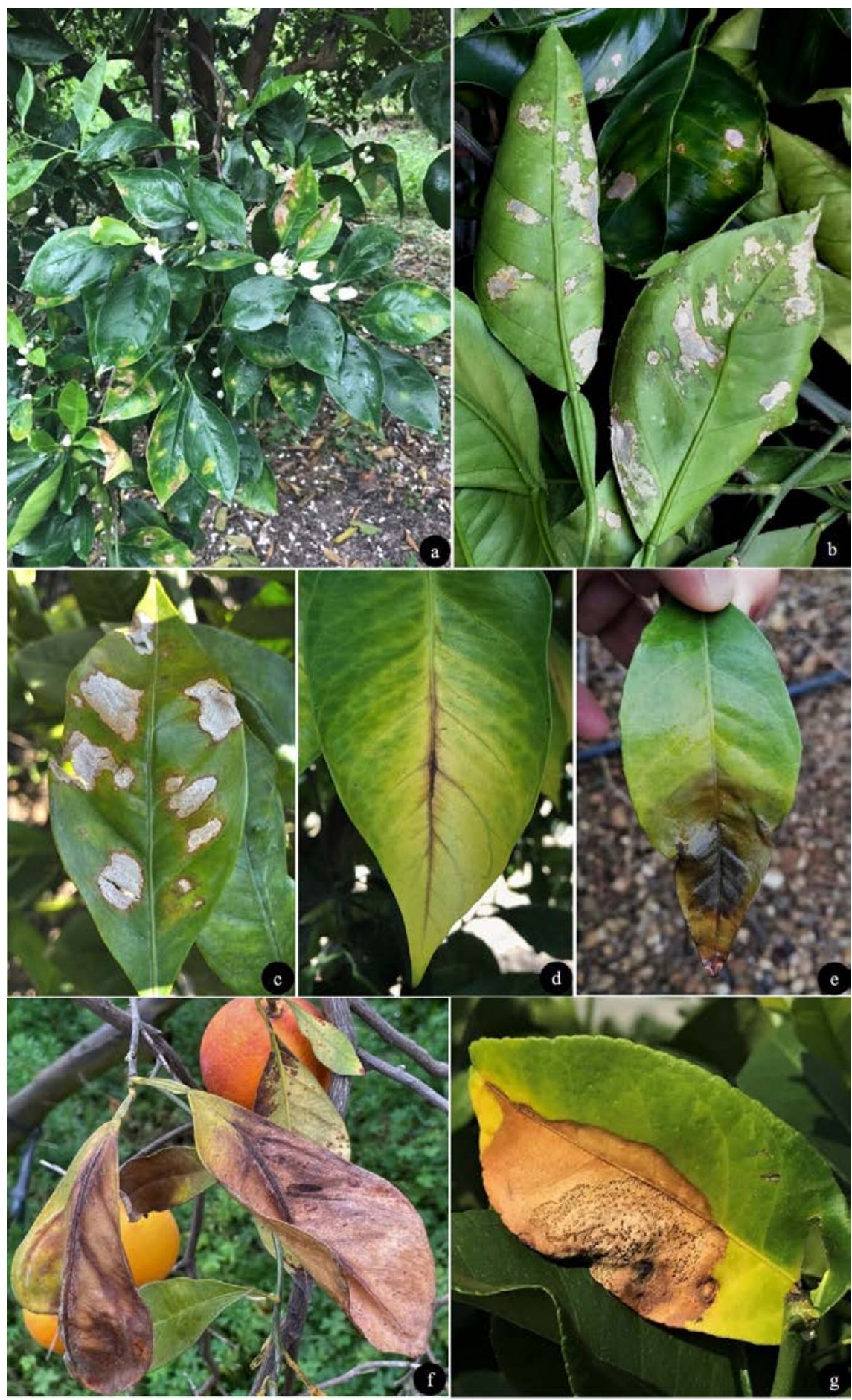

Figure 3. Anthracnose on leaf: (a) severe anthracnose on leaves of "Mandared" mandarin; (b) mesophyll collapse associated with anthracnose on bottom and top leaf pages of "Tarocco Lempso"; (c) irregular blighted grey to light brown lesions with a prominent purple margin and presence of fungal black acervuli on dead tissues; (d,e) leaf vein necrosis, leaf yellowing and tip wilting; (f) leaf blight; (g) anthracnose lesion on "Femminello Siracusano 2KR" after hail damage under humid condition. 


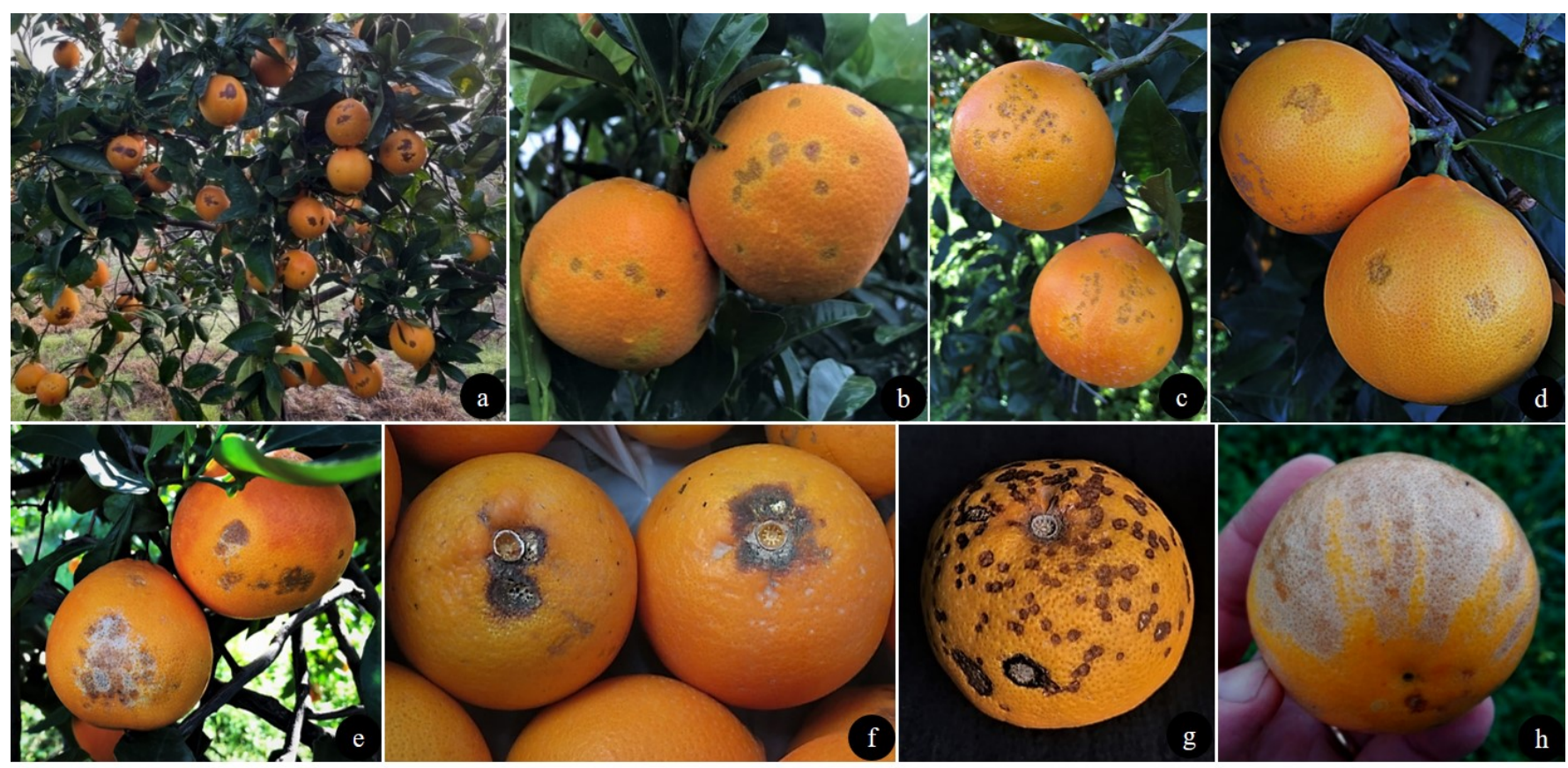

Figure 4. Pre-harvest anthracnose on fruit: (a) severe anthracnose fruit spot on "Tarocco Scirè VCR"; (b-e) small to large light, irregular and sunken lesions that could turn to black and formed acervuli on "Tarocco" blood orange accessions. (f) necrotic lesions at the stem-end of fruit that can cause pre-harvest fruit drop; (g) circular, small, necrotic lesions on "Tarocco Emanuele"; (h) tear stain on "Tarocco Sciara" fruit.

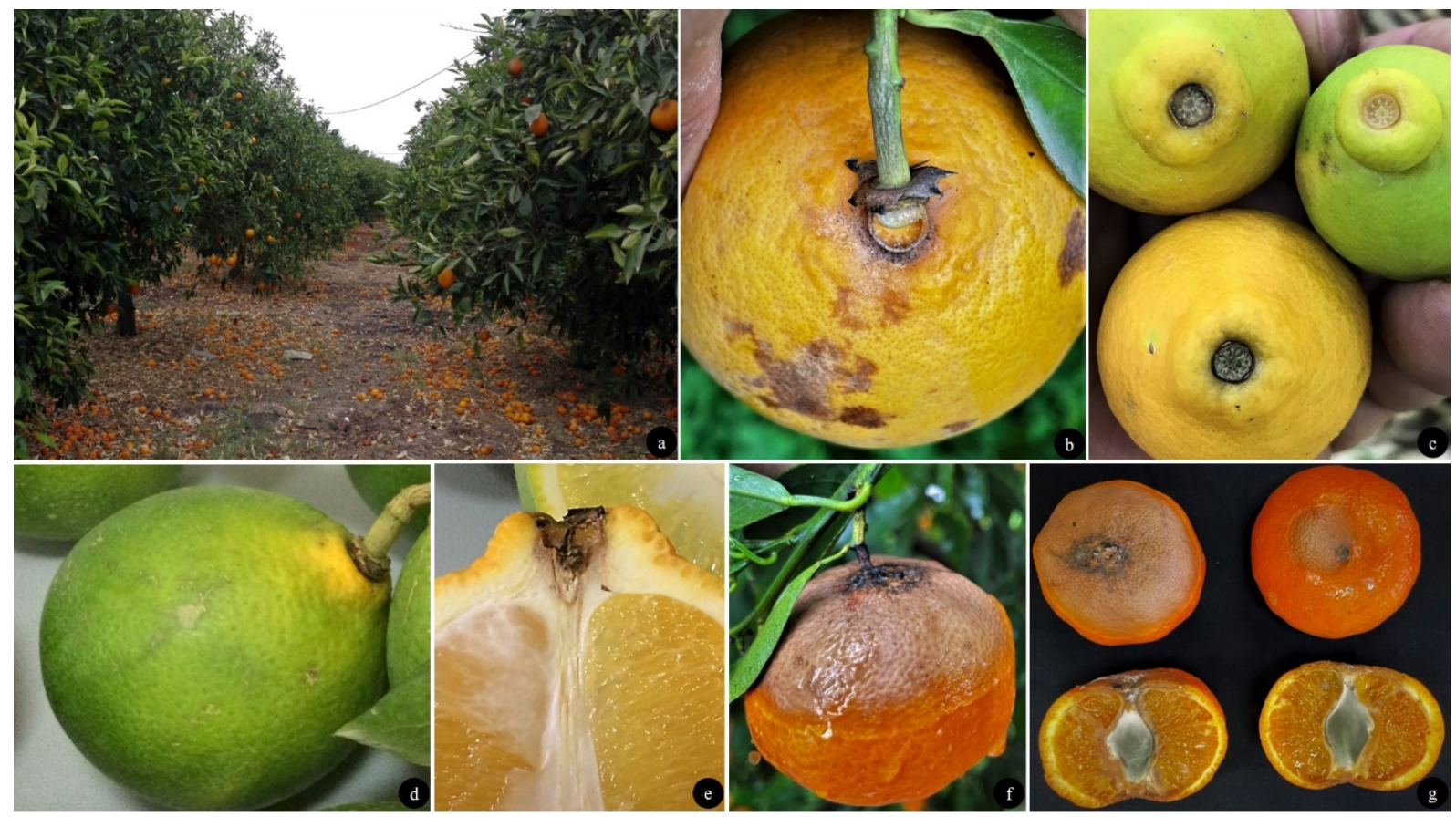

Figure 5. Pre-harvest fruit drop: (a) severe fruit drop on "Tarocco Scirè VCR" orchard; (b) calix blight and brown to blackish discoloration of the rind at the stem-end of immature "Tarocco Sciara" fruit; (c,d) fruit drop of immature fruit of "Tarocco Sciara" with premature coloring; (e) detail of a longitudinal section of fruit showing stem-end rot; (f) extensive black rot on "Mandalate" mandarin; (g) black rot symptom on central column of "Mandalate" mandarin. 


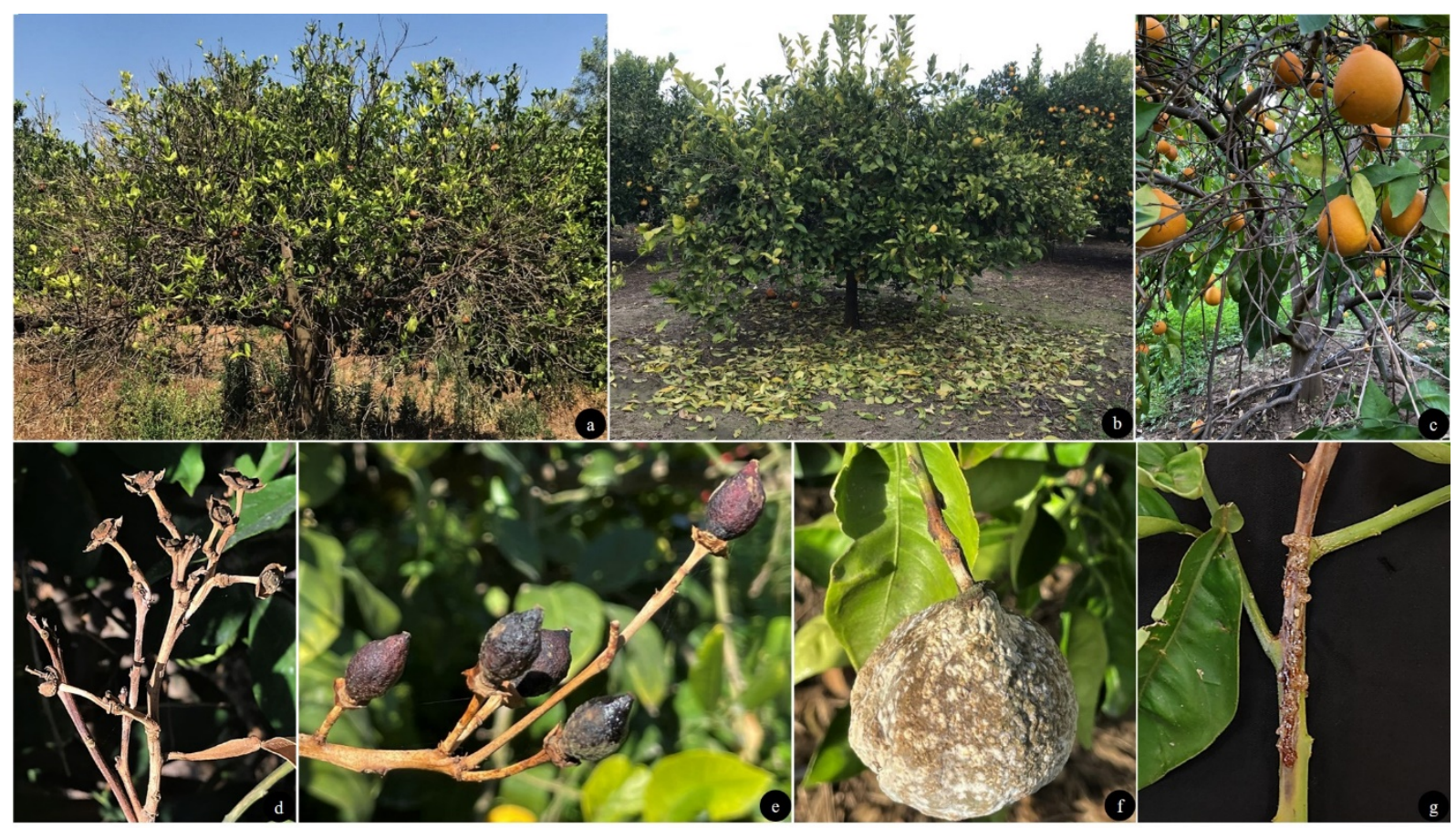

Figure 6. Twig dieback and defoliation: (a) severe twig dieback of "Tarocco Scirè VCR" tree; (b) severe defoliation of "Tarocco Sciré D2062 nucellare" tree; (c) detail of twigs blight on "Tarocco Sciara"; (d) blight of calyx and twigs of "Tarocco Meli"; (e) blight of fruitlet and twig of "Femminello Siracusano 2KR"; (f) mummified fruit with grey aerial hyphae of "Tarocco Sciara"; (g) gum exudation on "Tarocco Scirè VCR" twig.

\subsection{Isolation and Fungal Identification}

The repeated isolations performed during the survey period allowed us to refer the symptoms to known diseases or to determine the frequency of the association of Colletotrichum spp. and Alternaria spp. for less specific symptoms.

Typical Alternaria species was consistently associated with early fruit drop symptoms in all accessions, while Colletotrichum colonies have been found only occasionally and in association to the Alternaria isolates. Early fruit drop caused by Alternaria species occurred especially if the fruitlet is infected soon after petal fall and as a consequence even a small lesion causes immediate abscission [48]. Conversely, in our survey, the unusual necrosis of fruitlet that remained attached to the twig was also observed. Similar symptoms are also reported for post bloom fruit drop, a disease caused by C. abscissum and more recently by $C$. gloeosporioides $[3,25,26,49]$. However, typical post bloom fruit drop symptoms are restricted to open flowers causing blossom blight, orange brown lesion of petals with acervuli formation on the lesion, abscission of developing fruit, and the formation of persistent calyces [3].

Alternaria colonies were also consistently isolated from brown spot symptoms on leaf and fruit while Colletotrichum species was sometimes recovered in association to the Alternaria isolates. The characteristic symptoms observed on fruit could support the hypotheses of a marginal role of Colletotrichum spp. Symptoms of Alternaria brown spot on fruit and leaf caused by Alternaria alternata were reported in all Citrus producing countries on tangerine and their hybrids [37,50,51]; more recently severe symptoms were described on oranges and lemon accession in Sicily [6].

Typical Colletotrichum colonies were always recovered from anthracnose symptoms on leaf and fruit confirming the etiology of this symptoms-complex. These results are in accordance with the recent studies on anthracnose of citrus in Italy [5,9] and worldwide $[8,9,32,52]$. Conversely, in the same disease symptoms, leaf vein necrosis was exclusively associated in our survey to Colletotrichum species, unlike what was reported by Vicent et al. [53] which attributed this symptom to Alternaria species. 
Colonies of Alternaria were consistently isolated in most pre-harvest fruit drop symptomscomplex that showed light brown to blackish discoloration of the rind at or near the stemend of fruit, and from all fruit showing black rot. Occasionally, colonies of Colletotrichum species $(\sim 10 \%$ of relative frequency-RF) were recovered from calyx blight. In literature, Colletotrichum species causes pre-harvest fruit drop when lesions are located at stem-end of fruit [54]. Black rot caused by Alternaria species is reported as a significant postharvest disease that cause stem-end rot on fruit. Sometimes, the symptom may appear in the field prior to harvest at the stylar-end of fruit and it may cause premature fruit drop. Moreover, generally infected fruit does not show external symptoms of infection but only internal rot when cut $[55,56]$. Conversely, in our field survey, the infections at the stem-end of fruit caused fruit drop or alternatively, they extended from the stem-end of fruit to rind and along central column resulting in external and internal black rot.

Typical Colletotrichum colonies were consistently recovered ( $95 \% \mathrm{RF})$ from wither tip, twig dieback, and defoliation symptoms while Alternaria species was occasionally recovered ( $5 \% \mathrm{RF})$. Whiter tip and twig dieback caused by Colletotrichum species were widely reported on different citrus species worldwide [5,9,32], although A. alternata may cause defoliation and dieback of twig under appropriate environmental conditions [48]. All isolates of Alternaria showed colony morphology and conidia typical of the genus [57]. Colonies were olive-brown to black green and produced small, muriform, pigmented conidia allowing to identify small-spored Alternaria species. Conidia in long chains varied in shape from obpyriform to obclavate, ranging from 22.8 to $45.5 \times 5.5$ to $13.0 \mu \mathrm{m}$ with 3-6 transverse and 1-3 longitudinal septa. Subsequently, the species-level characterization was confirmed by sequencing data which were blasted against the NCBI's GenBank nucleotide database revealing high similarity with Alternaria species. Most of the characterized isolates belonged to the A. alternata, only a few of these were A. arborescens, confirming the previous results reported by Aiello et al. [6].

Colletotrichum colonies exhibited grey to white aerial mycelium with abundant dark conidiomata (acervuli) on the surface. Conidia in mass orange to pink were straight, cylindrical, and unicellular. The length and width of conidia produced ranged from 13.5 to $15 \times 3$ to $5 \mu \mathrm{m}$. Based on morphological features [58] and BLAST searches Colletotrichum isolates recovered from all described disease symptoms were identified as $C$. gloeosporioides ( $\sim 75 \%$ of isolates) and C. karstii ( $27 \%$ of isolates). Colletotrichum gloeosporioides is very commonly isolated from citrus, especially from $C$. sinensis, followed by C. karstii $[5,9,19,59]$ and C. abscissum [60].

\subsection{Germplasm Susceptibility Evaluation}

According to what was reported above, mean susceptibility degree (referred to average percentage disease data over time in the same citrus orchard) against different Alternaria and Colletotrichum symptoms was recorded within the four Citrus groups to make easier comparisons in germplasm response to fungal disease infections. Based on these data, it was possible to ascertain a very variable disease susceptibility over time for each disease symptoms among Citrus groups and, even to a greater extent, within each group among included accessions (ii) (Tables 1-3). 
Table 1. Susceptibility of "Tarocco" blood oranges to Alternaria and Colletotrichum disease symptoms over an eleven-year survey period.

\begin{tabular}{|c|c|c|c|c|c|c|c|c|}
\hline \multicolumn{2}{|c|}{ Germplasm } & \multicolumn{7}{|c|}{ Symptoms } \\
\hline Group & Accession & $\begin{array}{l}\text { Early Fruit } \\
\text { Drop } x, y, z\end{array}$ & $\begin{array}{l}\text { Alternaria Brown } \\
\text { Spot on Fruit }{ }^{x, y, z}\end{array}$ & $\begin{array}{l}\text { Alternaria Brown } \\
\text { Spot on Leaf } x, y, z\end{array}$ & $\begin{array}{l}\text { Anthracnose on } \\
\text { Leaf } x, y, z\end{array}$ & $\begin{array}{c}\text { Pre-Harvest } x, y, z \\
\text { Anthracnose on Fruit }\end{array}$ & $\begin{array}{l}\text { Pre-Harvest Fruit } \\
\text { Drop }{ }^{x, y, z}\end{array}$ & $\begin{array}{l}\text { Twig Dieback and } \\
\text { Defoliation } x, y, z\end{array}$ \\
\hline \multirow{14}{*}{ Tarocco } & Meli & $3.4 \pm 0.6(2-4)$ & $2.7 \pm 0.5(2-4)$ & $1.3 \pm 0.4(1-2)$ & $2.1 \pm 0.5(1-3)$ & $2.6 \pm 0.7(2-4)$ & $2.7 \pm 0.4(2-3)$ & $2.4 \pm 0.6(1-3)$ \\
\hline & Sciara & $3.2 \pm 0.7(2-5)$ & $2.7 \pm 0.5(2-3)$ & $1.4 \pm 0.5(1-2)$ & $3.8 \pm 0.8(2-5)$ & $4.0 \pm 0.6(2-5)$ & $4.0 \pm 0.8(2-5)$ & $3.5 \pm 0.8(2-5)$ \\
\hline & Gallo VCR & $2.2 \pm 0.6(1-3)$ & $2.0 \pm 0.8(1-3)$ & $1.1 \pm 0.2(1-2)$ & $2.6 \pm 0.7(1-4)$ & $2.5 \pm 0.8(1-4)$ & $2.4 \pm 0.6(1-3)$ & $2.8 \pm 0.6(1-4)$ \\
\hline & Gallo 898 & $2.7 \pm 0.5(2-3)$ & $2.7 \pm 0.6(2-4)$ & $1.2 \pm 0.4(1-2)$ & $2.6 \pm 0.5(2-3)$ & $2.5 \pm 0.5(2-3)$ & $2.2 \pm 0.7(1-3)$ & $2.8 \pm 0.4(2-3)$ \\
\hline & Sciré D2062 nucel. & $3.0 \pm 0.0(3-3)$ & $1.9 \pm 0.3(1-2)$ & $1.0 \pm 0.0(1-1)$ & $3.1 \pm 0.8(2-4)$ & $3.0 \pm 0.7(2-4)$ & $2.8 \pm 0.4(2-3)$ & $3.0 \pm 0.0(3-3)$ \\
\hline & Nucellare 57-1E-1 & $1.8 \pm 0.4(1-2)$ & $1.0 \pm 0.0(1-1)$ & $1.0 \pm 0.2(1-2)$ & $1.6 \pm 0.6(1-3)$ & $1.2 \pm 0.4(1-2)$ & $1.6 \pm 0.5(1-2)$ & $1.7 \pm 0.5(1-3)$ \\
\hline & Ippolito & $2.2 \pm 0.4(2-3)$ & $2.1 \pm 0.4(2-3)$ & $1.0 \pm 0.2(1-2)$ & $2.6 \pm 0.5(2-3)$ & $2.1 \pm 0.4(1-3)$ & $2.1 \pm 0.3(2-3)$ & $2.1 \pm 0.4(2-3)$ \\
\hline & Lempso & $3.4 \pm 0.7(2-5)$ & $1.6 \pm 0.6(1-3)$ & $1.1 \pm 0.2(1-2)$ & $3.4 \pm 0.7(2-4)$ & $3.0 \pm 0.8(2-4)$ & $2.8 \pm 0.6(2-4)$ & $3.6 \pm 0.7(3-5)$ \\
\hline & Sant'Alfio & $1.8 \pm 0.4(1-2)$ & $2.3 \pm 0.7(1-3)$ & $1.0 \pm 0.0(1-1)$ & $2.0 \pm 0.0(2-2)$ & $1.9 \pm 0.3(1-2)$ & $2.0 \pm 0.0(2-2)$ & $1.9 \pm 0.3(1-2)$ \\
\hline & Rosso & $2.0 \pm 0.0(2-2)$ & $1.8 \pm 0.4(1-2)$ & $1.2 \pm 0.4(1-2)$ & $2.0 \pm 0.0(2-2)$ & $1.8 \pm 0.4(1-2)$ & $2.2 \pm 0.4(2-3)$ & $2.0 \pm 0.7(1-3)$ \\
\hline & Galici & $1.9 \pm 0.3(1-2)$ & $1.2 \pm 0.4(1-2)$ & $1.0 \pm 0.0(1-1)$ & $2.2 \pm 0.4(2-3)$ & $2.0 \pm 0.5(1-3)$ & $2.2 \pm 0.4(2-3)$ & $2.2 \pm 0.4(2-3)$ \\
\hline & Tapi & $1.5 \pm 0.5(1-2)$ & $1.6 \pm 0.9(1-3)$ & $1.0 \pm 0.0(1-1)$ & $1.7 \pm 0.5(1-2)$ & $1.5 \pm 0.5(1-2)$ & $1.7 \pm 0.5(1-2)$ & $1.8 \pm 0.4(1-2)$ \\
\hline & Catania & $2.0 \pm 0.0(2-2)$ & $1.3 \pm 0.6(1-2)$ & $1.0 \pm 0.0(1-1)$ & $2.0 \pm 0.0(2-2)$ & $1.8 \pm 0.4(1-2)$ & $2.0 \pm 0.0(2-2)$ & $2.0 \pm 0.0(2-2)$ \\
\hline & Mean & $2.6 \pm 0.8$ & $1.9 \pm 0.6$ & $1.2 \pm 0.3$ & $2.6 \pm 0.8$ & $2.6 \pm 1.1$ & $2.6 \pm 0.9$ & $2.7 \pm 0.8$ \\
\hline
\end{tabular}

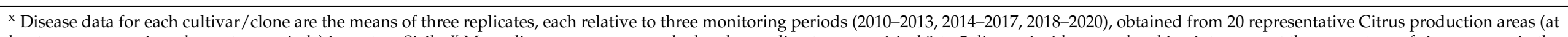

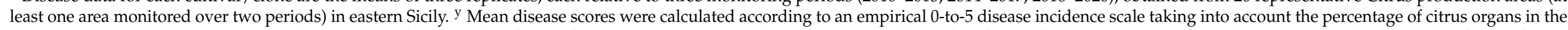

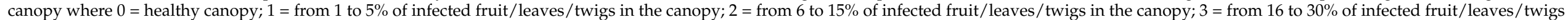

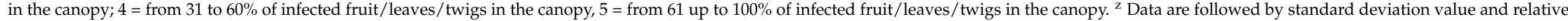
class range (min-max) monitored through surveyed time and period. 
Table 2. Susceptibility of other Blood oranges, Valencia orange and Navel oranges group to Alternaria and Colletotrichum disease symptoms over an eleven-year survey.

\begin{tabular}{|c|c|c|c|c|c|c|c|c|}
\hline \multicolumn{2}{|c|}{ Germplasm } & \multicolumn{7}{|c|}{ Symptoms } \\
\hline Group & Accession & $\begin{array}{l}\text { Early Fruit } \\
\text { Drop } x, y, z\end{array}$ & $\begin{array}{l}\text { Alternaria Brown } \\
\text { Spot on Fruit }{ }^{x, y, z}\end{array}$ & $\begin{array}{l}\text { Alternaria Brown } \\
\text { Spot on Leaf } x, y, z\end{array}$ & $\begin{array}{l}\text { Anthracnose on } \\
\text { Leaf } x, y, z\end{array}$ & $\begin{array}{c}\text { Pre-Harvest } x, y, z \\
\text { Anthracnose on Fruit }\end{array}$ & $\begin{array}{l}\text { Pre-Harvest Fruit } \\
\text { Drop }{ }^{x, y, z}\end{array}$ & $\begin{array}{l}\text { Twig Dieback and } \\
\text { Defoliation } x, y, z\end{array}$ \\
\hline \multirow{9}{*}{$\begin{array}{l}\text { Other blood } \\
\text { orange, } \\
\text { Valencia \& } \\
\text { Navel }\end{array}$} & Moro VCR & $2.3 \pm 0.7(1-3)^{z}$ & $1.0 \pm 0.0(1-1)^{z}$ & $1.7 \pm 0.5(1-2)^{z}$ & $1.9 \pm 0.3(1-2)^{z}$ & $1.9 \pm 0.6(1-3)^{z}$ & $1.7 \pm 0.5(1-2)^{z}$ & $2.3 \pm 0.5(2-3)^{z}$ \\
\hline & Moro Nucellare & $2.3 \pm 0.5(2-3)$ & $1.2 \pm 0.4(1-2)$ & $1.5 \pm 0.7(1-3)$ & $2.0 \pm 0.3(1-3)$ & $1.9 \pm 0.4(1-3)$ & $1.9 \pm 0.5(1-3)$ & $2.3 \pm 0.5(2-3)$ \\
\hline & Sanguinello & $2.9 \pm 1.3(1-4)$ & $2.0 \pm 0.9(1-3)$ & $1.9 \pm 0.8(1-3)$ & $1.7 \pm 0.5(1-2)$ & $1.8 \pm 0.7(1-3)$ & $2.2 \pm 1.0(1-4)$ & $2.7 \pm 0.5(2-3)$ \\
\hline & Valencia & $3.2 \pm 0.6(2-4)$ & $2.4 \pm 0.5(2-3)$ & $2.0 \pm 0.7(1-3)$ & $2.3 \pm 0.6(1-3)$ & $1.8 \pm 0.4(1-2)$ & $2.4 \pm 0.5(2-3)$ & $2.7 \pm 0.7(2-4)$ \\
\hline & NewHall VCR & $2.2 \pm 0.4(2-3)$ & $1.3 \pm 0.5(1-2)$ & $1.0 \pm 0.0(-1)$ & $1.3 \pm 0.5(1-2)$ & $1.7 \pm 0.5(1-2)$ & $1.9 \pm 0.3(1-2)$ & $2.1 \pm 0.5(1-3)$ \\
\hline & Lane Late & $2.4 \pm 0.5(2-3)$ & $2.6 \pm 0.5(2-3)$ & $1.0 \pm 0.0(1-1)$ & $1.5 \pm 0.5(1-2)$ & $1.5 \pm 0.5(1-2)$ & $1.8 \pm 0.4(1-2)$ & $1.9 \pm 0.5(1-3)$ \\
\hline & Chislett & $2.3 \pm 0.5(2-3)$ & $2.5 \pm 0.5(2-3)$ & $1.0 \pm 0.0(1-1)$ & $2.0 \pm 0.0(2-2)$ & $2.0 \pm 0.0(2-2)$ & $2.0 \pm 0.0(2-2)$ & $2.2 \pm 0.4(2-3)$ \\
\hline & Powell & $2.3 \pm 0.5(2-3)$ & $2.2 \pm 0.4(2-3)$ & $1.0 \pm 0.0(1-1)$ & $1.5 \pm 0.5(1-2)$ & $1.7 \pm 0.5(1-2)$ & $1.5 \pm 0.5(1-2)$ & $1.7 \pm 0.5(1-2)$ \\
\hline & Mean & $2.5 \pm 0.3$ & $1.8 \pm 0.6$ & $1.3 \pm 0.4$ & $1.8 \pm 0.3$ & $1.8 \pm 0.2$ & $1.9 \pm 0.3$ & $2.2 \pm 0.3$ \\
\hline
\end{tabular}

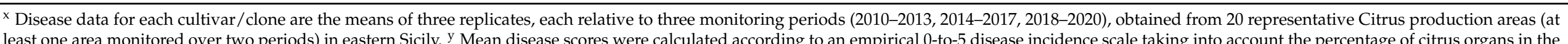

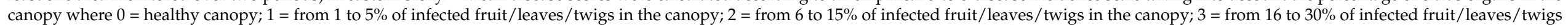

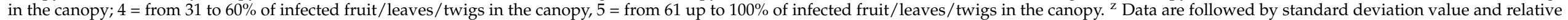
class range (min-max) monitored through surveyed time and period. 
Table 3. Susceptibility of Mandarin, Satsuma and Easy-peel and Lemon groups to Alternaria and Colletotrichum disease symptoms over an eleven-year survey.

\begin{tabular}{|c|c|c|c|c|c|c|c|c|}
\hline \multicolumn{2}{|c|}{ Germplasm } & \multicolumn{7}{|c|}{ Symptoms } \\
\hline Group & Accession & $\begin{array}{l}\text { Early Fruit } \\
\text { Drop }{ }^{x, y, z}\end{array}$ & $\begin{array}{l}\text { Alternaria Brown } \\
\text { Spot on Fruit }{ }^{x, y, z}\end{array}$ & $\begin{array}{l}\text { Alternaria Brown } \\
\text { Spot on Leaf } x, y, z\end{array}$ & $\begin{array}{l}\text { Anthracnose on } \\
\text { Leaf } x, y, z\end{array}$ & $\begin{array}{c}\text { Pre-Harvest } x, y, z \\
\text { Anthracnose on Fruit }\end{array}$ & $\begin{array}{l}\text { Pre-Harvest Fruit } \\
\text { Drop }{ }^{x, y, z}\end{array}$ & $\begin{array}{l}\text { Twig Dieback and } \\
\text { Defoliation } x, y, z\end{array}$ \\
\hline \multirow{10}{*}{$\begin{array}{c}\text { Mandarin, } \\
\text { Satsuma \& } \\
\text { Easy peel }\end{array}$} & Tacle & $3.2 \pm 1.0(2-5)^{z}$ & $1.5 \pm 0.5(1-2)^{z}$ & $1.2 \pm 0.4(1-2)^{\mathrm{z}}$ & $2.3 \pm 0.8(1-4)^{z}$ & $2.6 \pm 1.2(1-5)^{z}$ & $4.0 \pm 0.8(2-5)^{z}$ & $3.2 \pm 0.7(2-4)^{z}$ \\
\hline & Nova & $2.1 \pm 0.5(1-3)$ & $1.6 \pm 0.5(1-2)$ & $1.1 \pm 0.4(1-2)$ & $1.6 \pm 0.6(1-3)$ & $1.4 \pm 0.5(1-2)$ & $1.8 \pm 0.6(1-3)$ & $2.2 \pm 0.6(1-3)$ \\
\hline & Mandared & $3.5 \pm 1.4(2-5)$ & $1.6 \pm 0.5(1-2)$ & $1.5 \pm 0.5(1-2)$ & $4.2 \pm 0.7(3-5)$ & $1.9 \pm 0.3(1-2)$ & $4.4 \pm 0.5(4-5)$ & $4.6 \pm 0.5(4-5)$ \\
\hline & Yosemite Gold & $2.8 \pm 1.1(2-4)$ & $3.6 \pm 0.5(3-4)$ & $2.4 \pm 1.9(1-5)$ & $1.2 \pm 0.4(1-2)$ & $1.8 \pm 0.4(1-2)$ & $2.4 \pm 0.9(1-3)$ & $2.0 \pm 0.7(1-3)$ \\
\hline & Nadorcott & $2.0 \pm 0.0(2-2)$ & $1.7 \pm 0.6(1-2)$ & $1.0 \pm 0.0(1-1)$ & $2.0 \pm 0.0(2-2)$ & $1.0 \pm 0.0(1-1)$ & $2.0 \pm 0.0(2-2)$ & $2.0 \pm 0.0(2-2)$ \\
\hline & Satsuma Miagawa & $1.0 \pm 0.0(1-1)$ & $1.0 \pm 0.0(1-1)$ & $1.0 \pm 0.0(1-1)$ & $1.0 \pm 0.0(1-1)$ & $1.0 \pm 0.0(1-1)$ & $1.0 \pm 0.0(1-1)$ & $1.0 \pm 0.0(1-1)$ \\
\hline & Avana & $1.6 \pm 0.5(1-2)$ & $2.4 \pm 0.5(2-3)$ & $2.0 \pm 0.0(2-2)$ & $1.0 \pm 0.0(1-1)$ & $1.0 \pm 0.0(1-1)$ & $1.6 \pm 0.5(1-2)$ & $1.2 \pm 0.4(1-2)$ \\
\hline & Mandalate & $2.8 \pm 1.2(2-5)$ & $3.9 \pm 0.9(3-5)$ & $2.4 \pm 0.5(2-3)$ & $1.8 \pm 0.4(1-2)$ & $2.6 \pm 0.5(2-3)$ & $2.1 \pm 0.3(2-3)$ & $2.3 \pm 0.5(2-3)$ \\
\hline & Tardivo di Ciaculli & $2.0 \pm 0.0(2-2)$ & $3.1 \pm 0.6(2-4)$ & $1.7 \pm 0.7(1-3)$ & $1.1 \pm 0.3(1-2)$ & $1.1 \pm 0.3(1-2)$ & $1.3 \pm 0.5(1-2)$ & $1.7 \pm 0.5(1-2)$ \\
\hline & Orri & $1.0 \pm 0.0 *$ & $1.0 \pm 0.0$ * & $1.0 \pm 0.0$ * & $1.0 \pm 0.0 *$ & $1.0 \pm 0.0$ * & $1.0 \pm 0.0 *$ & $1.0 \pm 0.0^{*}$ \\
\hline \multirow{3}{*}{ Lemon } & $\begin{array}{l}\text { Femminello } \\
\text { Zagara Bianca }\end{array}$ & $2.6 \pm 0.8(2-4)^{z}$ & $1.8 \pm 0.4(1-2)^{z}$ & $1.7 \pm 0.5(1-2)^{z}$ & $1.0 \pm 0.0(1-1)^{z}$ & $1.0 \pm 0.0(1-1)^{z}$ & $0.0 \pm 0.0^{z}$ & $1.7 \pm 0.5(1-2)^{z}$ \\
\hline & $\begin{array}{c}\text { Femminello } \\
\text { Siracusano 2KR }\end{array}$ & $2.6 \pm 0.8(2-4)$ & $2.9 \pm 0.7(2-4)$ & $1.5 \pm 0.5(1-2)$ & $1.2 \pm 0.4(1-2)$ & $1.0 \pm 0.0(1-1)$ & $0.4 \pm 0.8(0-2)$ & $1.7 \pm 0.5(1-2)$ \\
\hline & Mean & $2.6 \pm 0.0$ & $2.4 \pm 0.8$ & $1.6 \pm 0.1$ & $1.1 \pm 0.1$ & $1.0 \pm 0.0$ & $0.2 \pm 0.3$ & $1.7 \pm 0.0$ \\
\hline
\end{tabular}

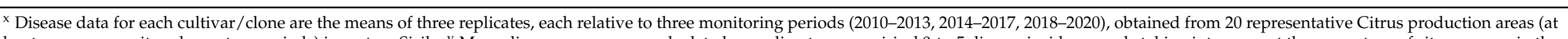

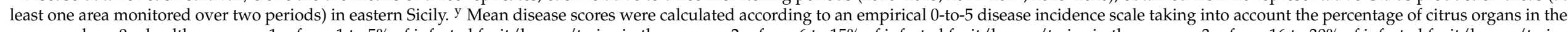

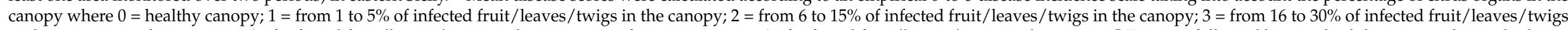

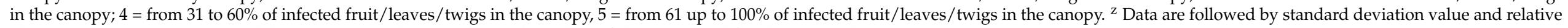
class range (min-max) monitored through surveyed time and period. * cultivar/clone surveyed for alone period in one area. 
Among all groups "Tarocco" blood orange accessions showed averagely the highest susceptibility degree to anthracnose on leaf and fruit, pre-harvest fruit drop, and twig dieback and defoliation (Tables 1-3). Nevertheless, a very variable plant response-ranging from low susceptibility/moderately tolerance degree with score values lesser than 2 (e.g., "Tarocco Nucellare 57-1E-1" and "Tarocco Tapi" accessions) to high/extreme susceptibility degree with score values more than 3.5 up to 5 (e.g., "Tarocco Emanuele" followed by "Tarocco Sciara" and "Tarocco Scirè VCR" accessions)-to these symptoms was ascertained within the "Tarocco" group (Table 1). Consequently, extirpation of "Tarocco Emanuele" citrus grove has been sometimes required in some production areas due to heavy production losses. Similarly, to what above detected, also for "Mandared" and, to a lesser extent, for "Tacle" accessions were averagely recorded the highest susceptibility degrees to these infections within Mandarin, Satsuma, and Easy peel group. Otherwise, lemon accessions were averagely the least susceptible to anthracnose on leaf and fruit, pre-harvest fruit drop and twig dieback and defoliation (Table 3) while both other Blood oranges, "Valencia" orange and Navel oranges and Mandarin, Satsuma and Easy peel groups showed generally an intermediate susceptibility response (Tables 2 and 3). In detail, "Femminello Zagara Bianca" lemon was the only tolerant citrus cultivar to pre-harvest fruit drop among all Citrus accessions examined since it did not show any symptoms over the entire survey period (Table 3).

As regards Alternaria brown spot on fruit and leaf and early fruit drop, lemon germplasm resulted averagely more susceptible to these fungal infections. In detail, accession "Femminello Siracusano 2KR" was more susceptible to Alternaria brown spot on fruit than "Femminello Zagara Bianca" (Table 3). Likewise to what happened for susceptibility distribution to previously described symptoms, also here a variability in response to these fungal infections was detected within each Citrus group. Specifically, "Mandalate," "Yosemite Gold," and "Tardivo di Ciaculli" were averagely the most susceptible to Alternaria brown spot on fruit infections within Mandarin, Satsuma, and Easy peel group and, additionally, among all Citrus germplasm tested. On the other hand, "Tarocco Emanuele," "Tarocco Meli," and "Tarocco Sciara," and "Tarocco Lempso" revealed averagely the most susceptible accessions to early fruit drop within "Tarocco" group. "Tarocco Meli," "Tarocco Sciara," "Tarocco Gallo 898," and "Tarocco Emanuele" were the most susceptible accessions to Alternaria brown spot on fruit (Tables 1 and 3).

Comprehensively, distribution of mean susceptibility to all disease symptoms among accessions was more homogeneous within other Blood oranges, "Valencia" orange and Navel oranges group than those recorded within other Citrus groups. It is noteworthy, to this regard, that only "Valencia" orange and, to a lesser extent, "Sanguinello" blood orange showed a certain susceptibility degree to early fruit drop and pre-harvest fruit drop (Table 2).

\subsection{Risk Assessment of Epidemic Outbreaks}

When field data were referred to potential risk of epidemic disease outbreak in Citrus orchards-i.e., maximum level of disease amount recorded during a cumulative 11year period survey - further substantial differences among disease symptoms and within germplasm were detected and additional considerations should be made (Figures 7-13).

Based on maximum value ( 5 and 4 score) of disease amount detected, the highest risk of epidemic disease outbreak within entire citrus germplasm was detected for early fruit drop, twig dieback and defoliation, pre-harvest fruit drop and pre-harvest anthracnose on fruit (Figures 7 and 10-13) followed, to a lesser extent, by anthracnose on leaf (Figure 11). Conversely, the potential risk of infection outbreaks was appreciably lower for Alternaria brown spot on fruit (Figure 8) and, even nearly negligible, for Alternaria leaf spot (Figure 9). 


\section{Early fruit drop}

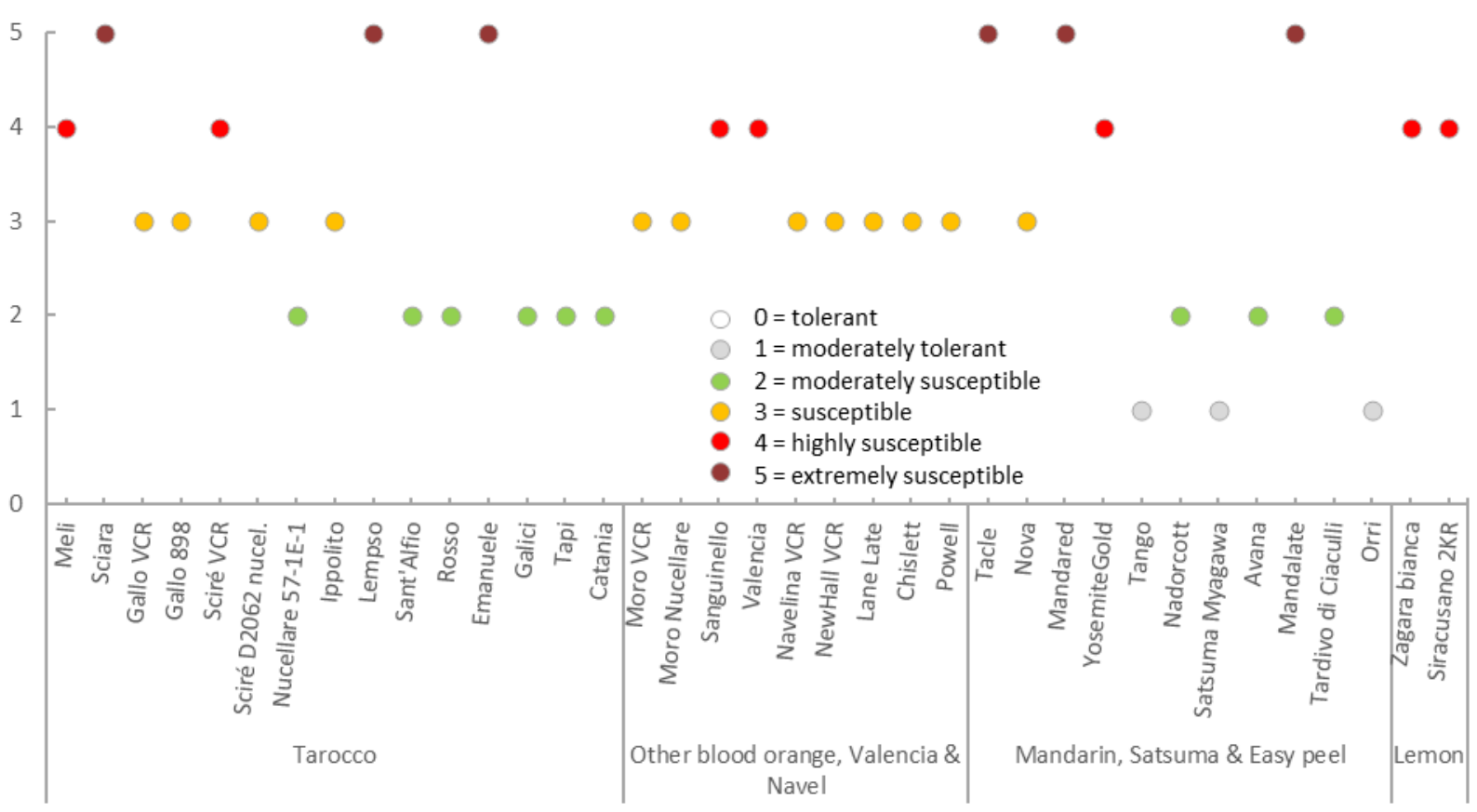

Figure 7. Maximum potential infection risk of early fruit drop recorded on detected Citrus germplasm. Data obtained from several Sicilian citrus production areas (from 1-to-20) within Citrus groups surveyed for three periods intercepting an eleven-year survey.

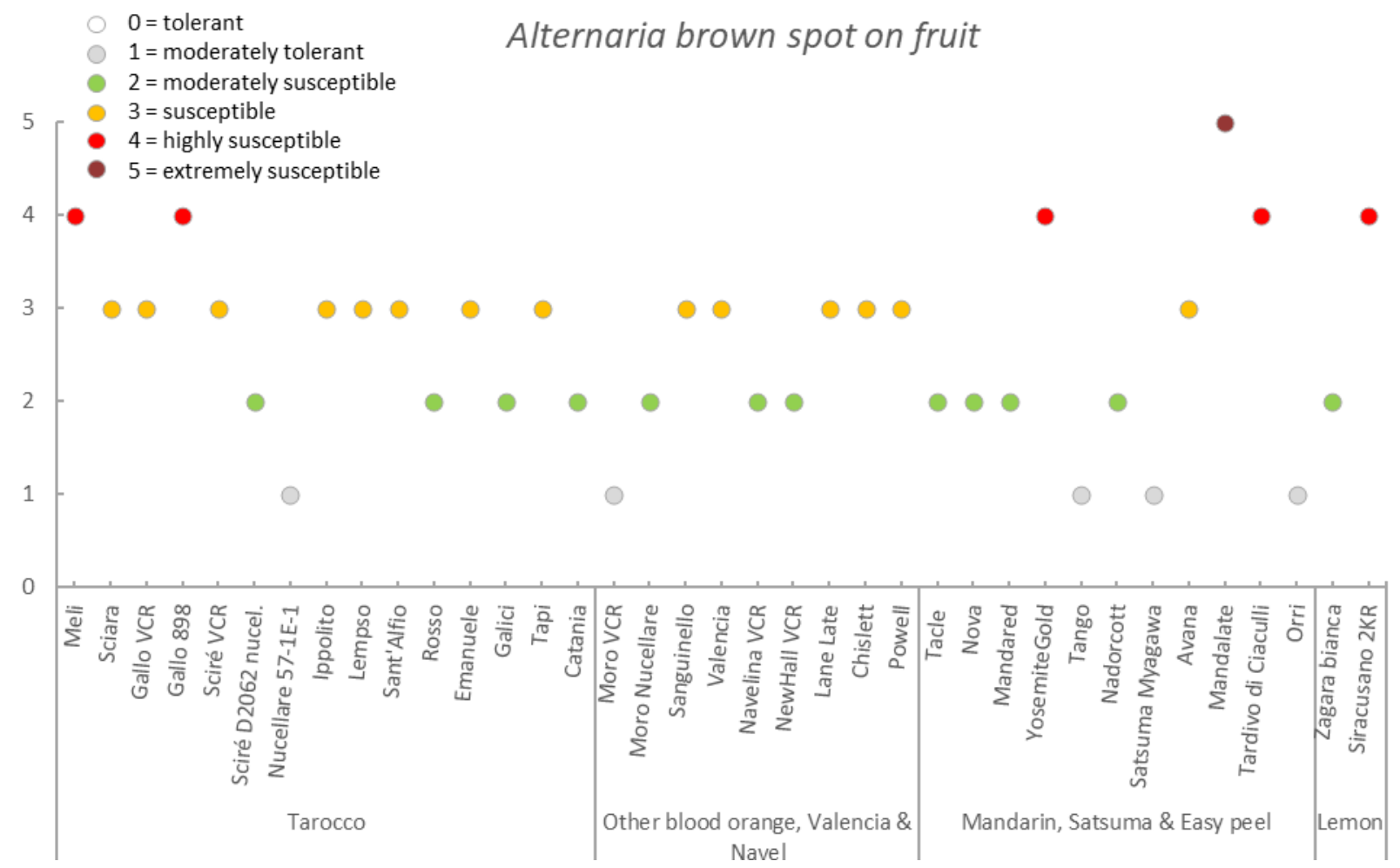

Figure 8. Maximum potential infection risk of Alternaria brown spot on fruit recorded on detected Citrus germplasm. Data obtained from several Sicilian citrus production areas (from 1-to-20) within Citrus groups surveyed for three periods intercepting an eleven-year survey. 


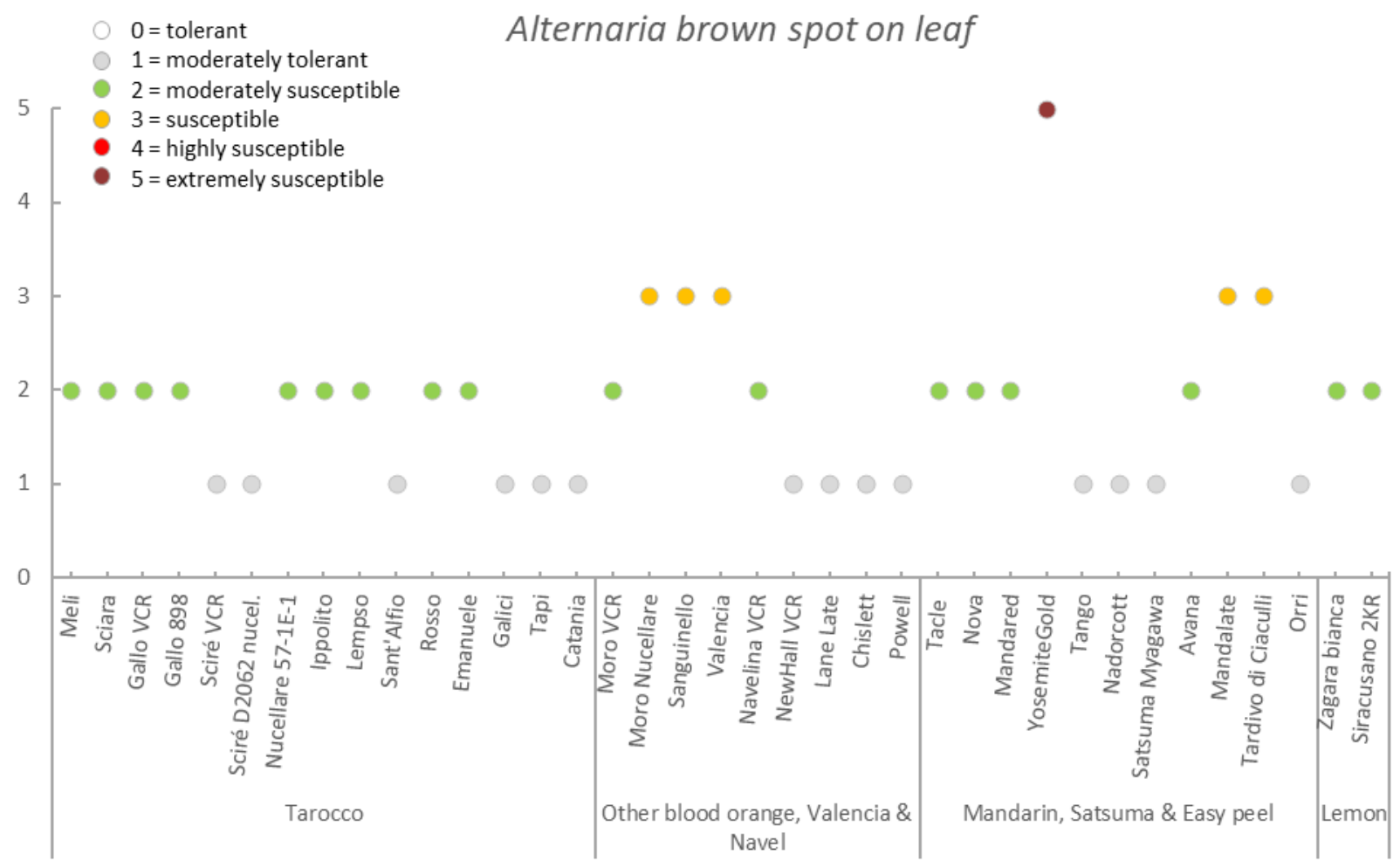

Figure 9. Maximum potential infection risk of Alternaria brown spot on leaf recorded on detected Citrus germplasm. Data obtained from several Sicilian citrus production areas (from 1-to-20) within Citrus groups surveyed for three periods intercepting an eleven-year survey.

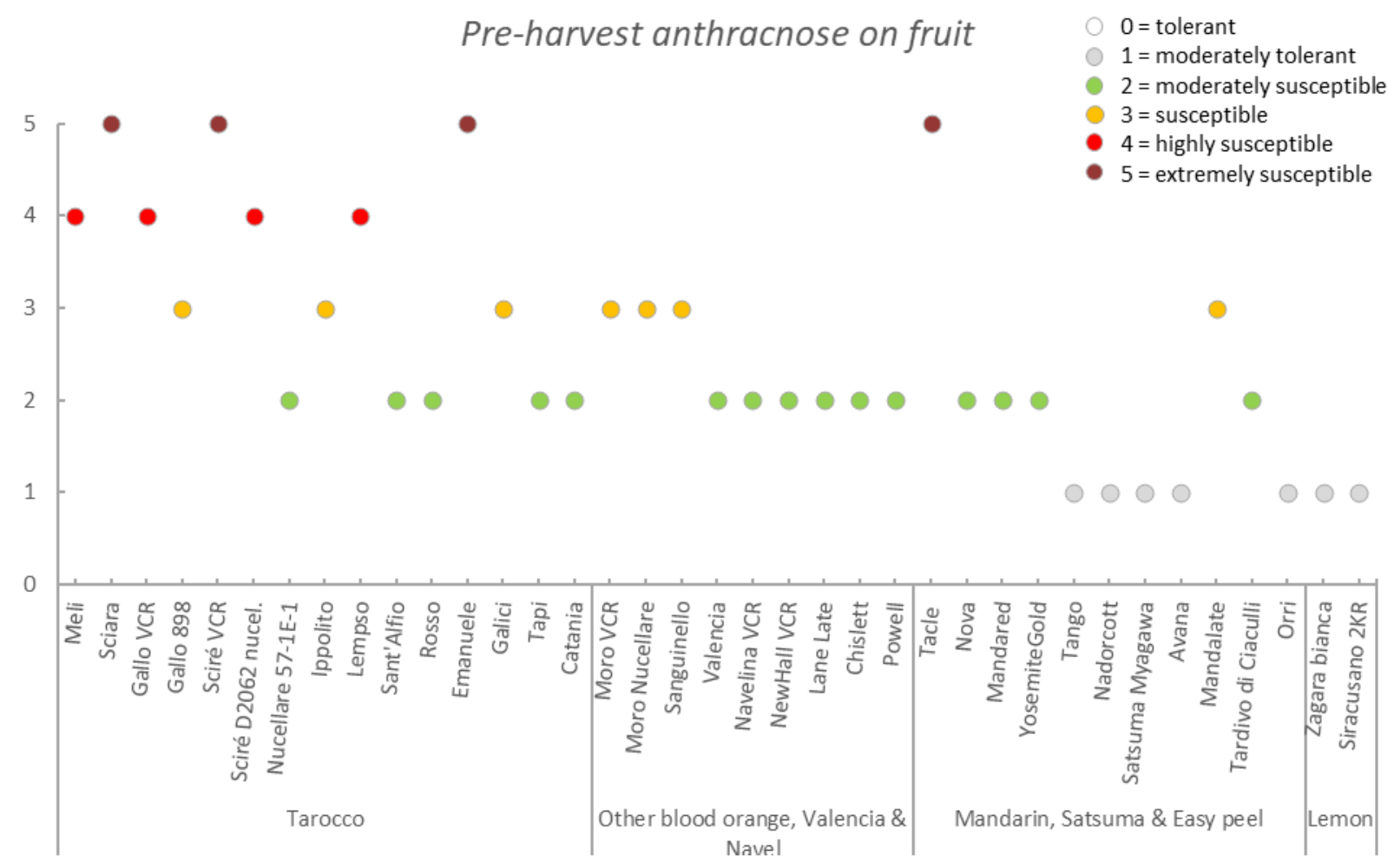

Figure 10. Maximum potential infection risk of pre-harvest anthracnose on fruit recorded on detected Citrus germplasm. Data obtained from several Sicilian citrus production areas (from 1-to-20) within Citrus groups surveyed for three periods intercepting an eleven-year survey. 


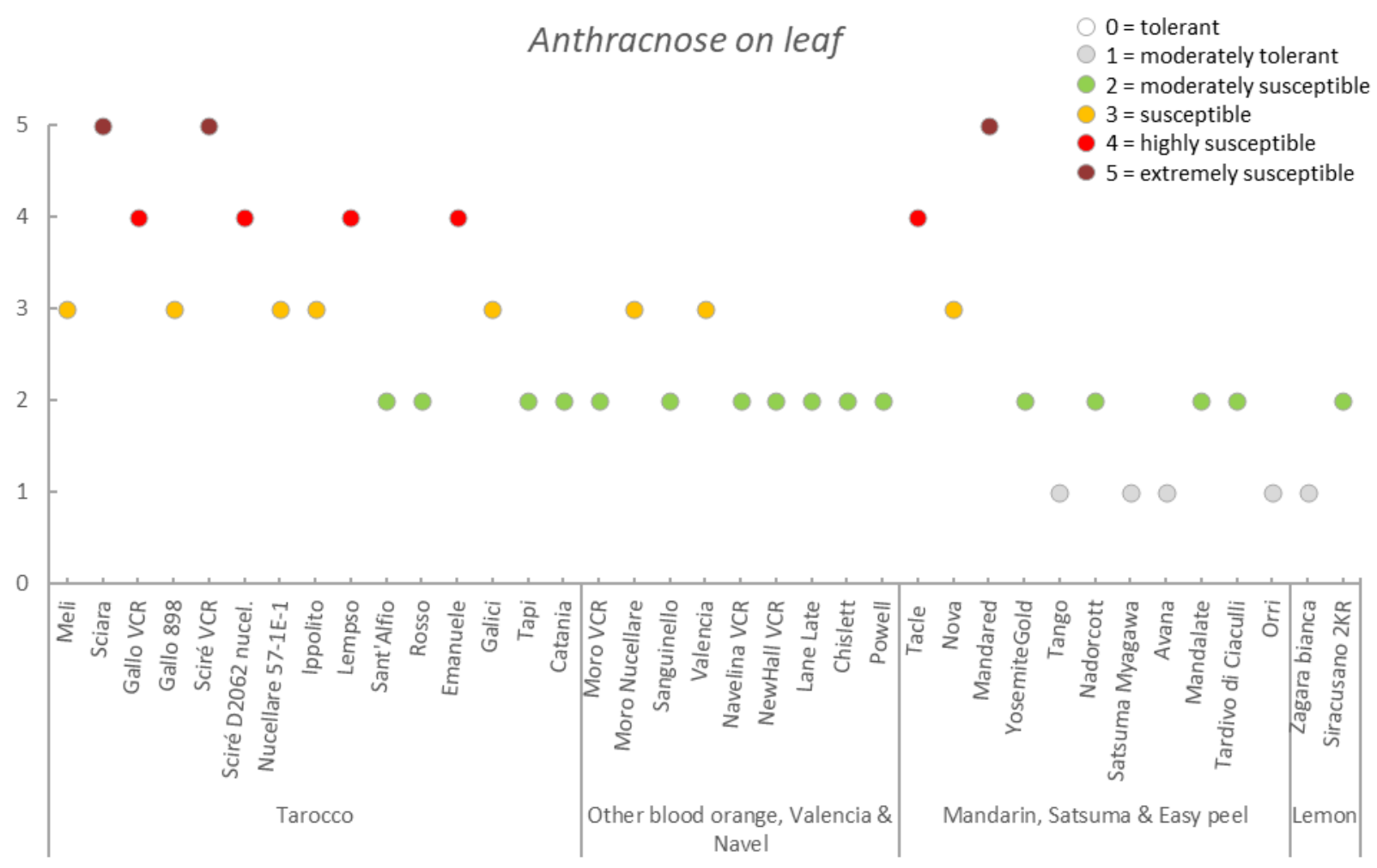

Figure 11. Maximum potential infection risk of anthracnose on leaf recorded on detected Citrus germplasm. Data obtained from several Sicilian citrus production areas (from 1-to-20) within Citrus groups surveyed for three periods intercepting an eleven-year survey.

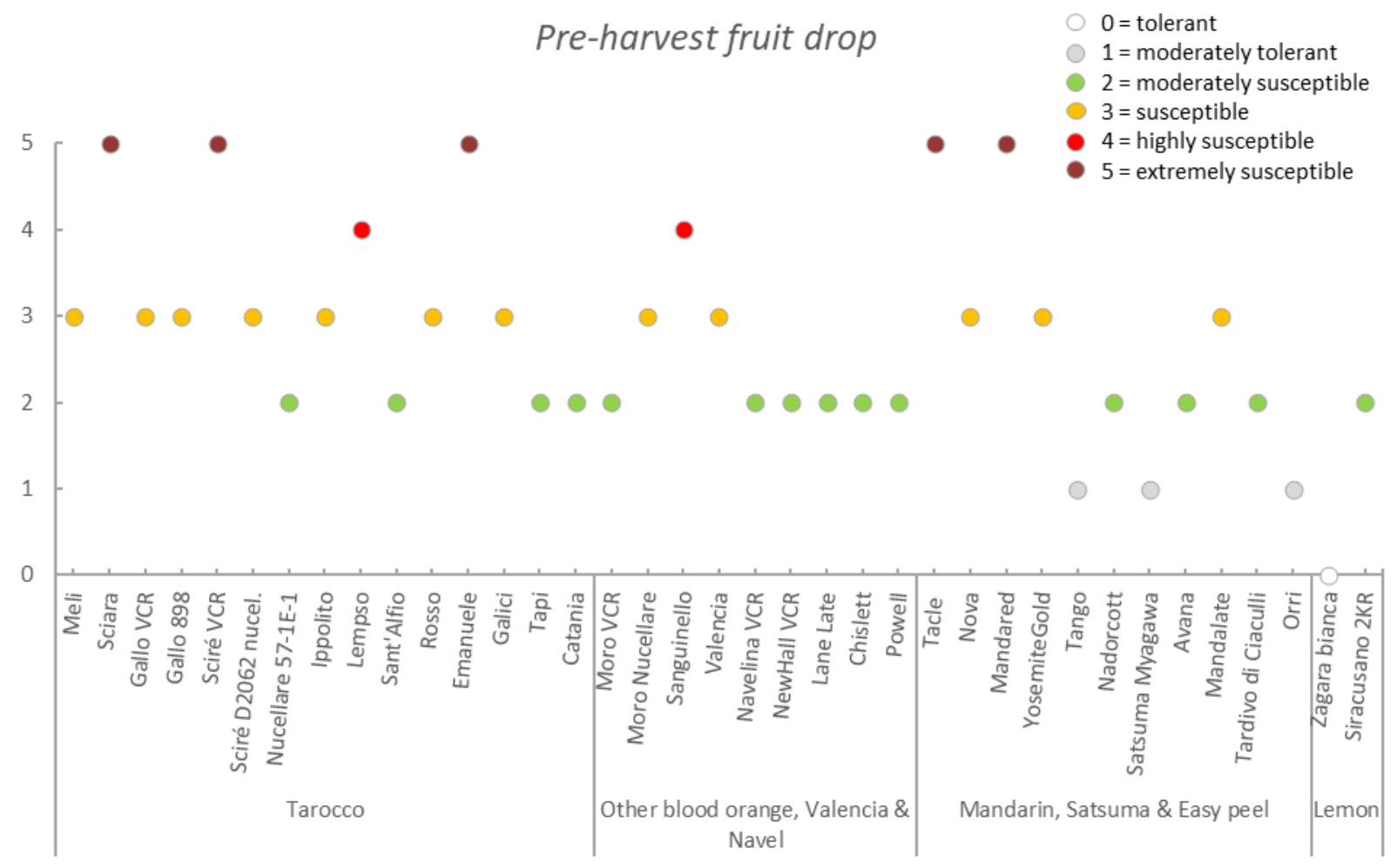

Figure 12. Maximum potential infection risk of pre-harvest fruit drop recorded on detected Citrus germplasm. Data obtained from several Sicilian citrus production areas (from 1-to-20) within Citrus groups surveyed for three periods intercepting an eleven-year survey. 


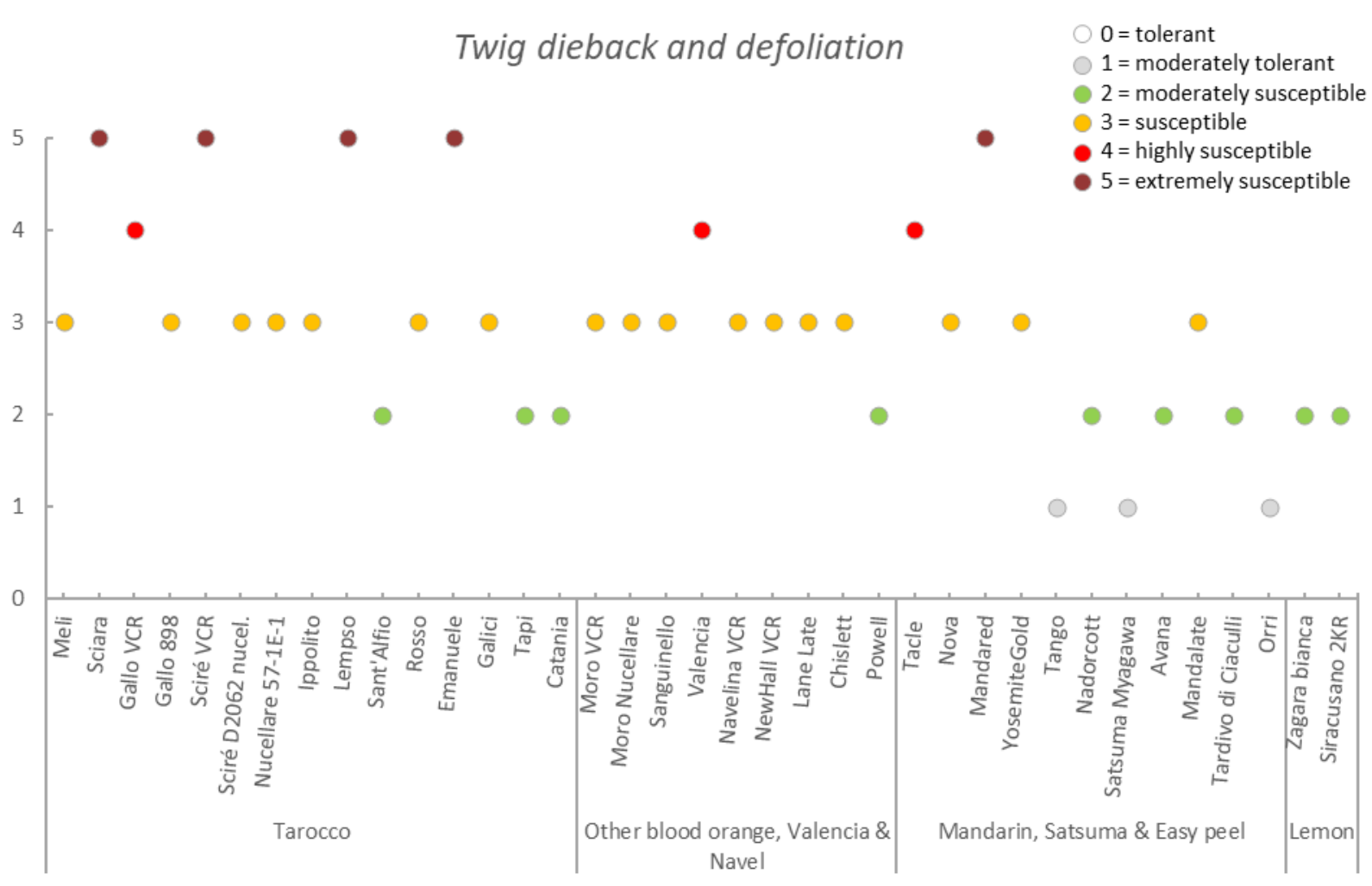

Figure 13. Maximum potential infection risk of twig dieback and defoliation recorded on detected Citrus germplasm. Data obtained from several Sicilian citrus production areas (from 1-to-20) within Citrus groups surveyed for three periods intercepting an eleven-year survey.

Comprehensively, "Tarocco" germplasm was more exposed to the occurrence of epidemic for early fruit drop, twig dieback, and defoliation and anthracnose on fruit and leaf under our agro-climatic conditions referable to Mediterranean basin. To this regard, "Tarocco Emanuele," "Tarocco Sciara," "Tarocco Sciré VCR," and "Tarocco Lempso" accessions were the most vulnerable to the onset of epidemic outbreaks, thus partially confirming the above reported disease susceptibility data. A high potential risk to these disease symptoms was also detected for "Tarocco Meli," "Tarocco Gallo VCR," and "Tarocco Sciré D2062 nucellare" accessions (Figures 7, 8 and 10-13).

On the other hand, "Tacle" and "Mandared" accessions were the most exposed to epidemic outbreaks of early fruit drop and pre-harvest fruit drop, twig dieback and defoliation and anthracnose on leaf within Mandarin, Satsuma, and Easy peel group (Figures 7 and 11-13). Moreover, "Tacle" was vulnerable to the onset of epidemic for preharvest anthracnose on fruit (Figure 10). The highest potential risk for Alternaria infections was recorded for "Yosemite Gold," "Mandalate," and to a lesser extent, for "Tardivo di Ciaculli" accessions (Figures 8 and 9). As expected, the first two accessions were exposed to the onset of epidemic outbreaks of early fruit drop (Figure 7).

As regards, lemon germplasm, a high potential risk of infection for early fruit drop was recorded for both "Femminello Zagara Bianca" and "Femminello Siracusano 2KR" (Figure 7). This latter cultivar was also exposed to high potential infection risk for Alternaria brown spot on fruit (Figure 8). According to the above mentioned data, the distribution over time of all disease symptoms within other Blood oranges, "Valencia" orange and Navel oranges group was the most homogeneous, and a high potential risk for early fruit drop infection was recorded only for "Sanguinello" blood orange and "Valencia" orange accessions (Figure 7). This latter accession was exposed also to high risk of infection for twig dieback and defoliation, whereas "Sanguinello" showed a high potential risk of pre-harvest fruit drop (Figures 12 and 13). 
Based on both mean susceptibility and potential risk of outbreaks data recorded for all disease symptoms (Table 1, Table 2, Table 3; Figures 7-13), "Tarocco Nucellare 57-1E1," "Tarocco Tapi," "Tarocco Sant'Alfio," and "Tarocco Catania" were the most tolerant accessions that could be recommended to Citrus growers in the Mediterranean basin under agroclimatic conditions more favorable for the occurrence of disease.

\section{Conclusions}

In this paper, we described recurrent disease symptoms that occur simultaneously in all surveyed germplasm in orchards covering a total cultivation area of approximately 1500 ha in Sicily. These symptoms were always relatable to both Alternaria and Colletotrichum species, alone and/or in mixed infections and with a variable ratio.

Our findings allowed to ascertain widespread and heavy symptoms on Citrus crop areas and to determine susceptibility and potential risk of epidemic outbreaks on 37 Citrus accessions under natural disease pressure conditions over an eleven-year survey period (2010-2020). These symptoms included early fruit drop, brown spot, and anthracnose on fruit and leaves, pre-harvest fruit drop, and twig blight and defoliation.

The high diseases pressure detected in all surveyed areas forces Citrus growers to adopt scheduled fungicide spray programs. Unfortunately, chemical control leads to harmful and hazardous consequences for human and environmental health and, moreover, the occurrence of widespread resistance phaenomena further discourages its continuous applications [61-64].

As a consequence, selection of tolerant Citrus germplasm should be considered a promising alternative to limit the use of synthetic fungicides to manage Alternaria and Colletotrichum infections in Citrus groves.

For Alternaria, brown spot marker-assisted selection (MAS) is available for the selection of new resistant Citrus accessions [65,66]. It well-known that identification of a genomic region very rich in disease resistance homologous genes or loci is one of the most reliable and efficient tool to select potential tolerant cultivars. To the light of these findings, we retain that these techniques could be useful only in the early stage of a Citrus breeding program.

To confirm this, present study clearly showed that the field evaluation of Citrus germplasm susceptibility is strictly needed before the large-scale adoption of new varieties in a specific risk-area, above all if mixed infections, disease pressure, complex pathogenic mechanisms or agronomical traits could be involved in plant response to fungal disease.

Comprehensively, the adoption of some Citrus accessions (i.e., "Tarocco Emanuele," "Tarocco Scirè VCR," "Tarocco Sciara," and "Tarocco Lempso" or "Tacle," "Mandared," "Mandalate," and "Yosemite Gold") should not be encouraged since their production expecially in wet and cold areas is heavily compromised. On the other hand, a certain degree of tolerance observed in some accessions (i.e., "Tarocco Nucellare 57-1E-1," "Tarocco Tapi," "Tarocco Sant'Alfio," and "Tarocco Catania" or "Femminello Zagara Bianca") represent a valuable resource and can be employed in breeding programs for genetic improvement of Citrus accessions.

Author Contributions: Conceptualization, G.P. and A.V.; methodology, A.A. and D.A.; software, A.V.; validation, A.V., D.A., and V.G.; formal analysis, A.V.; investigation, A.A. and D.A.; resources, A.A. and G.P.; data curation, A.V. and D.A.; writing—original draft preparation, A.V., D.A., V.G.; writingreview and editing, G.P. and A.V.; visualization, D.A.; supervision, G.P.; project administration, G.P.; funding acquisition, G.P. and A.V. All authors have read and agreed to the published version of the manuscript.

Funding: This research was funded and supported by following grants: Programma Ricerca di Ateneo MEDIT-ECO UNICT 2020-2022 Linea 2-University of Catania (Italy); Starting Grant 2020, University of Catania (Italy); Fondi di Ateneo 2020-2022, University of Catania (Italy), Linea Open Access. Research Project 2016-2018, University of Catania 5A722192134.

Institutional Review Board Statement: Not applicable. 
Informed Consent Statement: Not applicable.

Data Availability Statement: The data presented in this study are available on request from the corresponding author.

Acknowledgments: All authors are grateful to Carmelo Cantarella and citrus growers of all orchards for their technical support and availability.

Conflicts of Interest: The authors declare no conflict of interest.

\section{References}

1. FAOSTAT. Food and Agriculture Organization of the United Nations. 2021. Available online: http://www.fao.org/faostat/en/ \#home (accessed on 24 November 2020).

2. Timmer, L.W.; Solel, Z.; Orozco-Santos, M. Alternaria brown spot of mandarins. In Compendium of Citrus Diseases; Timmer, L.W., Garnsey, S.M., Graham, J.H., Eds.; APS Press, Inc.: St. Paul, MN, USA, 2000; pp. 19-21.

3. Lima, W.G.; Spósito, M.B.; Amorim, L.; Gonçalves, F.P.; Melo de Filho, P.A. Colletotrichum gloeosporioides, a new causal agent of citrus post-bloom fruit drop. Eur. J. Plant Pathol. 2011, 131, 157-165. [CrossRef]

4. Guarnaccia, V.; Crous, P.W. Species of Diaporthe on Camellia and Citrus in the Azores Islands. Phytopathol. Mediterr. 2018, 57, 307-319.

5. Aiello, D.; Carrieri, R.; Guarnaccia, V.; Vitale, A.; Lahoz, E.; Polizzi, G. Characterization and pathogenicity of Colletotrichum gloeosporioides and C. karstii causing pre-harvest disease on Citrus sinensis in Italy. J. Phytopathol. 2015, 163, 168-177. [CrossRef]

6. Aiello, D.; Guarnaccia, V.; Azzaro, A.; Polizzi, G. Alternaria brown spot on new clones of sweet orange and lemon in Italy. Phytopathol. Mediterr. 2020, 59, 131-145.

7. Guarnaccia, V.; Van Niekerk, J.; Crous, P.W.; Sandoval-Denis, M. Neocosmospora spp. associated with dry root rot of citrus in South Africa. Phytopathol. Mediterr. 2021, 60, 81-102. [CrossRef]

8. Wang, W.; de Silva, D.D.; Moslemi, A.; Edwards, J.; Ades, P.K.; Crous, P.W.; Taylor, P.W.J. Colletotrichum Species Causing Anthracnose of Citrus in Australia. J. Fungi 2021, 7, 47. [CrossRef] [PubMed]

9. Guarnaccia, V.; Groenewald, J.Z.; Polizzi, G.; Crous, P.W. High Species Diversity in Colletotrichum Associated with Citrus Diseases in Europe. Pers. Mol. Phylogeny Evol. Fungi 2017, 39, 32-50. [CrossRef]

10. Guarnaccia, V.; Gehrmann, T.; Silva-Junior, G.J.; Fourie, P.H.; Haridas, S.; Vu, D.; Spatafora, J.; Martin, F.M.; Robert, V.; Grigoriev, I.V.; et al. Phyllosticta citricarpa and sister species of global importance to Citrus. Mol. Plant Pathol. 2019, 20, 1619-1635. [CrossRef]

11. Juroszek, P.; Racca, P.; Link, S.; Farhumand, J.; Kleinhenz, B. Overview on the review articles published during the past 30 years relating to the potential climate change effects on plant pathogens and crop disease risks. Plant Pathol. 2020, 69, 179-193. [CrossRef]

12. Möller, M.; Stukenbrock, E.H. Evolution and genome architecture in fungal plant pathogens. Nat. Rev. Microbiol. 2017, 15, 756-771. [CrossRef]

13. Bezerra, J.D.P.; Crous, P.W.; Aiello, D.; Gullino, M.L.; Polizzi, G.; Guarnaccia, V. Genetic Diversity and Pathogenicity of Botryosphaeriaceae Species Associated with Symptomatic Citrus Plants in Europe. Plants 2021, 10, 492. [CrossRef]

14. Rhaiem, A.; Taylor, P.W.J. Colletotrichum gloeosporioides associated with anthracnose symptoms on citrus, a new report for Tunisia. Eur. J. Plant Pathol. 2016, 146, 219-224. [CrossRef]

15. Mayorquin, J.S.; Wang, D.H.; Twizeyimana, M.; Eskalen, A. Identification, distribution, and pathogenicity of Diatrypaceae and Botryosphaeriaceae associated with citrus branch canker in the Southern California desert. Plant Dis. 2016, 100, $2402-2413$. [CrossRef]

16. Fuentes-Aragón, D.; Silva-Rojas, H.V.; Guarnaccia, V.; Mora-Aguilera, J.A.; Aranda-Ocampo, S.; Bautista-Martínez, N.; Téliz-Ortíz, D. Colletotrichum species causing anthracnose on avocado fruit in Mexico: Current status. Plant Pathol. 2020, 69, 1513-1528. [CrossRef]

17. Khodadadi, F.; González, J.B.; Martin, P.L.; Giroux, E.; Bilodeau, G.J.; Peter, K.A.; Doyle, V.P.; Aćimović, S.G. Identification and characterization of Colletotrichum species causing apple bitter rot in New York and description of $C$. noveboracense sp. nov. Sci. Rep. 2020, 10, 11043. [CrossRef]

18. Vitale, A.; Alfenas, A.C.; Siqueira, D.L.D.; Magistà, D.; Perrone, G.; Polizzi, G. Cultivar resistance against Colletotrichum asianum in the world collection of mango germplasm in southeastern Brazil. Plants 2020, 9, 182. [CrossRef]

19. Peng, L.; Yang, Y.; Hyde, K.D.; Bahkali, A.H.; Liu, Z. Colletotrichum Species on Citrus Leaves in Guizhou and Yunnan Provinces, China. Cryptogam. Mycol. 2012, 33, 267-283.

20. Cheng, B.P.; Huang, Y.H.; Song, X.B.; Peng, A.T.; Ling, J.F.; Chen, X. First Report of Colletotrichum siamense Causing Leaf Drop and Fruit Spot of Citrus reticulata Blanco cv. Shiyue Ju in China. Plant Dis. 2013, 97, 1508. [CrossRef] [PubMed]

21. Huang, F.; Chen, G.Q.; Hou, X.; Fu, Y.S.; Cai, L.; Hyde, K.D.; Li, H.Y. Colletotrichum Species Associated with Cultivated Citrus in China. Fungal Divers. 2013, 61, 61-74. [CrossRef]

22. Douanla-Meli, C.; Unger, J. Phylogenetic Study of The Colletotrichum Species on Imported Citrus Fruits Uncovers a Low Diversity and A New Species in The Colletotrichum gigasporum Complex. Fungal Biol. 2017, 121, 858-868. [CrossRef] [PubMed] 
23. Kunta, M.; Park, J.W.; Vedasharan, P.; da Graça, J.V.; Terry, M.D. First Report of Colletotrichum queenslandicum on Persian Lime Causing Leaf Anthracnose in The United States. Plant Dis. 2018, 102, 677. [CrossRef]

24. Hu, W.L.; Ma, Y.Z.; Chen, J.Z. First Report of Citrus sinensis Anthracnose Caused by Colletotrichum fructicola in China. Plant Dis. 2019, 103, 1018. [CrossRef]

25. Silva, A.O.; Savi, D.C.; Gomes, F.B.; Gos, F.M.V.R.; Silva, G.J.; Glienke, C. Identification of Colletotrichum species associated with postbloom fruit drop in Brazil through GAPDH sequencing analysis and multiplex PCR. Eur. J. Plant Pathol. 2016, 147, 731-748. [CrossRef]

26. McGovern, R.J.; Seijo, T.E.; Hendricks, K.; Roberts, P.D. New report of Colletotrichum gloeosporioides causing postbloom fruit drop on citrus in Bermuda. Can. J. Plant Pathol. 2012, 34, 187-194. [CrossRef]

27. Damm, U.; Cannon, P.F.; Woudenberg, J.H.C.; Crous, P.W. The Colletotrichum acutatum species complex. Stud. Mycol. 2012, 73, 37-113. [CrossRef]

28. Perrone, G.; Magistà, D.; Ismail, A.M. First report of Colletotrichum kahawae subsp. ciggaro on mandarin in Italy. J. Plant Pathol. 2016, 98, 682 .

29. Uysal, A.; Kurt, S. First Report of Colletotrichum karstii Causing Anthracnose on Citrus in the Mediterranean Region of Turkey. J. Plant Pathol. 2019, 101, 753. [CrossRef]

30. Daoud, H.B.H.; Baraldi, E.; Iotti, M.; Leonardi, P.; Boughalleb-M'hamdi, N. Characterization and Pathogenicity of Colletotrichum spp. Causing Citrus Anthracnose in Tunisia. Phytopathol. Mediterr. 2019, 58, 175-185.

31. Ramos, A.P.; Talhinhas, P.; Sreenivasaprasad, S.; Oliveira, H. Characterization of Colletotrichum gloeosporioides, As the Main Causal Agent of Citrus Anthracnose, and C. karstii As Species Preferentially Associated with Lemon Twig Dieback in Portugal. Phytoparasitica 2016, 44, 549-561. [CrossRef]

32. Benyahia, H.; Jrifia, A.; Smaili, C.; Afellah, M.; Lamsetef, Y.; Timmer, L.W. First Report of Colletotrichum gloeosporioides Causing Wither-tip on Twigs and Tear Stain on Fruit of Citrus in Morocco. Plant Pathol. 2003, 52, 798. [CrossRef]

33. Pérez-Mora, J.L.; Mora-Romero, G.A.; Beltrán-Peña, H.; García-León, E.; Lima, N.B.; Camacho-Tapia, M.; Tovar-Pedraza, J.M. First Report of Colletotrichum siamense and C. gloeosporioides Causing Anthracnose of Citrus Spp. In Mexico. Plant Dis. 2020, 105, 496. [CrossRef]

34. Cruz-Lagunas, B.; Ortega-Acosta, S.A.; Reyes-García, G.; Toribio-Jiménez, J.; Juárez-López, P.; Guillén-Sánchez, D.; Damián-Nava, A.; Romero-Ramírez, Y.; Palemón-Alberto, F. Colletotrichum gloeosporioides Causes Anthracnose on Grapefruit (Citrus paradisi) In Mexico. Australas. Plant Dis. Notes 2020, 15, 31. [CrossRef]

35. Fayyaz, A.; Sahi, S.T.; Nawaz-ul-Rehman, M.S.; Amrao, L. Molecular Characterization of Fungal Pathogens Associated with Citrus Wither-tip/Dieback from Major Citrus Growing Areas of Punjab, Pakistan. Int. J. Agric. Biol. 2020, 23, 1165-1170.

36. Mahiout, D.; Bendahmane, B.S.; Benkada, M.Y.; Mekouar, H.; Berrahal, N.; Rickauer, M. First Report of Colletotrichum gloeosporioides on Citrus in Algeria. Phytopathol. Mediterr. 2018, 57, 355-359.

37. Timmer, L.W.; Peever, T.L.; Solel, Z.; Akimitsu, K. Alternaria diseases of citrus-novel pathosystems. Phytopathol. Mediterr. 2003, 42, 99-112.

38. Peever, T.L.; Su, G.; Carpenter-Boggs, L.; Timmer, L.W. Molecular systematics of citrus-associated Alternaria species. Mycologia 2004, 96, 119-134. [CrossRef]

39. Dewdney, M.M.; Timmer, L.W. Florida Citrus Pest Management Guide: Alternaria Brown Spot; Institute of Food and Agricultural Sciences University of Florida: Gainesville, FL, USA, 2010.

40. Gama, A.B.; Baggio, J.S.; Rebello, C.S.; Lourenco, S.D.A.; Gasparoto, M.C.D.G.; da Silva Junior, G.J.; Peres, N.A.; Amorim, L. Sensitivity of Colletotrichum acutatum Isolates from Citrus to Carbendazim, Difenoconazole, Tebuconazole, and Trifloxystrobin. Plant Dis. 2020, 104, 1621-1628. [CrossRef]

41. Chitolina, G.M.; Silva-Junior, G.J.; Feichtenberger, E.; Pereira, R.G.; Amorim, L. Distribution of Alternaria alternata isolates with resistance to quinone outside inhibitor (QoI) fungicides in Brazilian orchards of tangerines and their hybrids. Crop Prot. 2021, 141, 105493. [CrossRef]

42. Piccirillo, G.; Carrieri, R.; Polizzi, G.; Azzaro, A.; Lahoz, E.; Fernández-Ortuño, D.; Vitale, A. In vitro and in vivo activity of QoI fungicides against Colletotrichum gloeosporioides causing fruit anthracnose in Citrus sinensis. Sci. Hortic. 2018, $236,90-95$. [CrossRef]

43. White, T.J.; Bruns, T.; Lee, S.; Taylor, J.W. Amplification and direct sequencing of fungal ribosomal RNA genes for phylogenetics. In PCR Protocols: A Guide to Methods and Applications; Innis, M.A., Gelfand, D.H., Sninsky, J.J., White, T.J., Eds.; Academic Press: San Diego, CA, USA, 1990; pp. 315-322.

44. Woundernberg, J.H.C.; Seidl, M.F.; Groenewald, J.Z.; DeVries, M.; Stielow, J.B.; Thomma, B.P.H.J.; Crous, P.W. Alternaria section Alternaria: Species, formae speciales or pathotypes? Stud. Mycol. 2015, 82, 1-21. [CrossRef] [PubMed]

45. Carbone, I.; Kohn, L. A Method for Designing Primer Sets for Speciation Studies in Filamentous Ascomycetes. Mycologia 1999, 91, 553-556. [CrossRef]

46. Chung, W.H.; Chung, W.C.; Peng, M.T.; Yang, H.R.; Huang, J.W. Specific detection of benzimidazole resistance in Colletotrichum gloeosporioides from fruit crops by PCR-RFLP. New Biotechnol. 2010, 27, 17-24. [CrossRef] [PubMed]

47. Templeton, M.D.; Rikkerink, E.H.A.; Solon, S.L.; Crowhurst, R.N. Cloning and molecular characterization of the glyceraldehyde3-phosphate dehydrogenase-encoding gene and cDNA from the plant pathogenic fungus Glomerella cingulata. Gene 1992, 122, 225-230. [CrossRef] 
48. Simmons, E.G. Alternaria themes and variations (236-243). Classification of citrus pathogens. Mycotaxon 1999, 70, $263-323$.

49. Peres, N.A.; Mackenzie, S.J.; Peever, T.L.; Timmer, L.W. Postbloom fruit drop of citrus and key lime anthracnose are caused by distinct phylogenetic lineages of Colletotrichum acutatum. Phytopathology 2008, 98, 345-352. [CrossRef]

50. Peever, T.L.; Ibanez, A.; Akimitsu, K.; Timmer, L.W. Worldwide phylogeography of the citrus brown spot pathogen, Alternaria alternata. Phytopathology 2002, 9, 794-802. [CrossRef] [PubMed]

51. Akimitsu, K.; Peever, T.L.; Timmer, L.W. Molecular, ecological and evolutionary approaches to understanding Alternaria diseases of citrus. Mol. Plant Pathol. 2003, 4, 435-436. [CrossRef] [PubMed]

52. Yin, L.F.; Du, S.F.; Cai, M.L.; Luo, C.X. Identification of Anthracnose of Wild Citrus. Southwest China J. Agric. Sci. 2017, 30, 590-594.

53. Vicent, A.; Armengol, J.; Sales, R.; García-Jiménez, J.; Alfaro-Lassala, F. First Report of Alternaria Brown Spot of Citrus in Spain. Plant Dis. 2000, 84, 1044. [CrossRef] [PubMed]

54. Kaur, R.; Rewal, H.S.; Sethi, A. Pre-harvest stem-end rot in citrus cultivars due to Colletotrichum gloeosporioides. Eur. J. Hort Sci. 2007, 72, 20-25.

55. Brown, G.E.; Eckert, J.W. Alternaria rot. In Compendium of Citrus Diseases; Timmer, L.W., Garnsey, S.M., Graham, J.H., Eds.; APS Press, Inc.: St. Paul, MN, USA, 2000; p. 37.

56. Peever, T.L.; Carpenter-Boggs, L.W.; Timmer, L.W.; Carris, L.M.; Bhatia, A. Citrus Black rot is caused by phylogenetically distinct lineages of Alternaria alternata. Phytopathology 2005, 95, 512-518. [CrossRef]

57. Simmons, E.G. Alternaria: An Identification Manual; CBS Fungal Biodiversity Centre: Utrecht, The Netherlands, 2007.

58. Sutton, B.C. The genus Glomerella and its anamorph Colletotrichum. In Colletotrichum Biology, Pathology and Control; Bailey, J.A., Jeger, M.J., Eds.; CAB International: Wallingford, UK, 1992.

59. Cannon, P.F.; Buddie, A.G.; Bridge, P.D. The typification of Colletotrichum gloeosporioides. Mycotaxon 2008, 104, $189-204$.

60. Frare, G.F.; Couto, H.T.Z.; Ciampi-Guillardi, M.; Amorim, L. The causal agent of citrus postbloom fruit drop, Colletotrichum acutatum, can survive on weeds. Australas. Plant Pathol. 2016, 45, 339-346. [CrossRef]

61. Runkle, J.; Flocks, J.; Economos, J.; Dunlop, A.L. A systematic review of Mancozeb as a reproductive and developmental hazard. Environ. Int. 2017, 99, 29-42. [CrossRef]

62. Wang, Z.; Kottawatta, K.S.A.; Kodithuwakku, S.P.; Fernando, T.S.; Lee, Y.L.; Ng, E.H.Y.; Yeung, W.S.B.; Lee, K.F. The fungicide Mancozeb reduces spheroid attachment onto endometrial epithelial cells through downregulation of estrogen receptor $\beta$ and integrin $\beta 3$ in Ishikawa cells. Ecotoxicol. Environ. Saf. 2021, 208, 111606. [CrossRef] [PubMed]

63. Triantafyllidis, V.; Zotos, A.; Kosma, C.; Kokkotos, E. Environmental implications from long-term Citrus cultivation and wide use of $\mathrm{Cu}$ fungicides in Mediterranean soils. Water Air Soil Pollut. 2020, 231, 218. [CrossRef]

64. Lamichhane, J.R.; Osdaghi, E.; Behlau, F.; Köhl, J.; Jones, J.B.; Aubertot, J.N. Thirteen decades of antimicrobial copper compounds applied in agriculture. A review. Agron. Sustain. Dev. 2018, 38, 28. [CrossRef]

65. Cuenca, J.; Aleza, P.; Garcia-lor, A.; Ollitrault, P.; Navarro, L. Fine mapping for identification of Citrus Alternaria brown spot candidate resistance genes and development of new SNP markers for marker-assisted selection. Front. Plant. Sci. 2016, 7, 1948. [CrossRef]

66. Arlotta, C.; Ciacciulli, A.; Strano, M.C.; Cafaro, V.; Salonia, F.; Caruso, P.; Licciardello, C.; Russo, G.; Malcolm Smith, M.W.; Cuenca, J.; et al. Disease resistant Citrus breeding using newly developed high resolution melting and CAPS protocols for Alternaria brown spot marker assisted selection. Agronomy 2020, 10, 1368. [CrossRef] 